University of Nebraska - Lincoln

DigitalCommons@University of Nebraska - Lincoln

$12-2006$

\title{
Relational Leadership Theory: Exploring the social processes of leadership and organizing
}

Mary Uhl-Bien

University of Nebraska-Lincoln, mbien2@unl.edu

Follow this and additional works at: https://digitalcommons.unl.edu/leadershipfacpub

Part of the Management Sciences and Quantitative Methods Commons

Uhl-Bien, Mary, "Relational Leadership Theory: Exploring the social processes of leadership and organizing" (2006). Leadership Institute Faculty Publications. 19.

https://digitalcommons.unl.edu/leadershipfacpub/19

This Article is brought to you for free and open access by the Leadership Institute at DigitalCommons@University of Nebraska - Lincoln. It has been accepted for inclusion in Leadership Institute Faculty Publications by an authorized administrator of DigitalCommons@University of Nebraska - Lincoln. 
Published in The Leadership Quarterly 17:6 (December 2006), pp. 654-676:

The Leadership Quarterly Yearly Review of Leadership; doi 10.1016/j.leaqua.2006.10.007

Copyright (C) 2006 Elsevier Inc. Used by permission.

http://www.sciencedirect.com/science/journal/10489843

Published online November 16, 2006.

\title{
Relational Leadership Theory: Exploring the social processes of leadership and organizing
}

\author{
Mary Uhl-Bien \\ Department of Management \\ University of Nebraska-Lincoln \\ Lincoln, NE 68588 USA
}

\begin{abstract}
Relational leadership is a relatively new term in the leadership literature, and because of this, its meaning is open to interpretation. In the present article I describe two perspectives of relational leadership: an entity perspective that focuses on identifying attributes of individuals as they engage in interpersonal relationships, and a relational perspective that views leadership as a process of social construction through which certain understandings of leadership come about and are given privileged ontology. These approaches can be complementary, but their implications for study and practice are quite different. After reviewing leadership research relative to these two perspectives I offer Relational Leadership Theory (RLT) as an overarching framework for the study of leadership as a social influence process through which emergent coordination (e.g., evolving social order) and change (e.g., new approaches, values, attitudes, behaviors, ideologies) are constructed and produced. This framework addresses relationships both as an outcome of investigation (e.g., How are leadership relationships produced?) and a context for action (e.g., How do relational dynamics contribute to structuring?). RLT draws from both entity and relational ontologies and methodologies to more fully explore the relational dynamics of leadership and organizing.
\end{abstract}

Keywords: relational leadership, entity perspectives, relationality

We consider the relational perspective and [the approaches within it] ... to be at the forefront of emerging leadership thrusts. ... The relational focus is one that moves beyond unidirectional or even reciprocal leader/follower relationships to one that recognizes leadership wherever it occurs; it is not restricted to a single or even a small set of formal or informal leaders; and, in its strongest form, functions as a dynamic system embedding leadership, environmental, and organizational aspects. (Hunt \& Dodge, 2000, p. 448).

While the concept of relationship-oriented behavior has been around since the earliest formal studies of leadership in organizations (Stogdill \& Coons, 1957), the term relational leadership is surprisingly new (Brower et al., 2000; Drath, 2001; Murrell, 1997; Uhl-Bien, 2003; Uhl-Bien, 2005). Because of this, its meaning is still uncertain. In traditional management discourse, the term relational means that "an individual likes people and thrives on relationships" (Lipman-Blumen, 1996, p. 165). Traditional research on leadership examines behavioral styles that are relationship-oriented (Likert, 1961), meaning considerate and supportive (Stogdill, Goode, \& Day, 1962) or leadership behaviors focused on developing high quality, 
trusting, work relationships (Brower et al., 2000; Graen and Scandura, 1987; Graen and Uhl-Bien, 1995; Uhl-Bien et al., 2000).

In recently developing discourse (Drath, 2001; Hosking, in press; Murrell, 1997), however, the term relational is being used to describe something quite different for leadership - a view of leadership and organization as human social constructions that emanate from the rich connections and interdependencies of organizations and their members (cf., Bradbury and Lichtenstein, 2000; Hosking et al., 1995). In contrast to a more traditional orientation, which considers relationships from the standpoint of individuals as independent, discrete entities (i.e., individual agency) (Bradbury and Lichtenstein, 2000; Hosking et al., 1995), a "relational" orientation starts with processes and not persons, and views persons, leadership and other relational realities as made in processes (Hosking, in press).

The more traditional orientation, which can be called an entity perspective because it focuses on individual entities, is consistent with an epistemology of an objective truth and a Cartesian dogma of a clear separation between mind and nature (Bradbury \& Lichtenstein, 2000). It assumes that: a) individuals have a "knowing mind," b) individuals have access to the contents of their mind (mind contents and knowledge are viewed as properties of entities, as individual possessions), and c) these entities can be distinguished from other entities (i.e., people) and the environment (Dachler \& Hosking, 1995). As such, the "knowing" individual is understood as the architect and controller of an internal and external order which makes sense with respect to the array of their personal "possessions" (their mind contents) (Dachler \& Hosking, 1995). This view approaches relationship-based leadership by focusing on individuals (e.g., leaders and followers) and their perceptions, intentions, behaviors, personalities, expectations, and evaluations relative to their relationships with one another (e.g., Hollander, 1978; Lord et al., 1999; Uhl-Bien et al., 2000). Dachler \& Hosking (1995) call this approach a "subject-object" understanding of relationships: "Social relations are enacted by subjects to achieve knowledge about, and influence over, other people and groups" (p.3).

The second, and less well-known, relational perspective views knowledge as socially constructed and socially distributed, not as "mind stuff" constructed or accumulated and stored by individuals: "That which is understood as real is differently constructed in different relational and historical/cultural settings" (Dachler \& Hosking, 1995, p. 4). Taking a relational orientation means recognizing that organizational phenomena exist in interdependent relationships and intersubjective meaning: “... [K]nowing occurs between two subjects or phenomena simultaneously, therefore we must attend to the multiple meanings and perspectives that continuously emerge..." (Bradbury \& Lichtenstein, 2000, p. 552). From this perspective, knowing is always a process of relating; relating is a constructive, ongoing process of meaning making - an actively relational process of creating (common) understandings on the basis of language; meaning can never be finalized, nor has it any ultimate origin, it is always in the process of making; and meanings are limited by socio-cultural contexts (Dachler \& Hosking, 1995). Applied to leadership (Dachler and Hosking, 1995; Hosking, in press), a relational orientation does not focus on identifying attributes of individuals involved in leadership behaviors or exchanges, but rather on the social construction processes by which certain understandings of leadership come about and are given privileged ontology (cf., Meindl, 1995).

In the sections below I review leadership theory relative to these two perspectives. As we will see in this discussion, although both entity and relational approaches view leadership as a social process, what they mean by process, particularly with respect to their ontology and epistemology, is quite different. The former views relational processes as centered in individuals' perceptions and cognitions as they engage in exchanges and influence relationships with one another, while the latter views persons and organizations as ongoing multiple constructions made "in" processes and not the makers "of" processes (Hosking, 2000). As will be described later in the article, these different ontologies result in very different ways of conceptualizing and operationalizing relational leadership, with the former adopting primarily a variable-based approach and the latter more of a constructionist approach.

Following this review, I present an overarching framework for the investigation of relational leadership. I identify relational leadership as a social influence process through which emergent coordination (i.e., evolving social order) and change (e.g., new values, attitudes, approaches, behaviors, and ideologies) are constructed and produced. This perspective does not restrict leadership to hierarchical positions or roles. Instead it views leadership as occurring in relational dynamics throughout the organization; as will be discussed below, it also acknowledges the importance of context in the study of these relational dynamics (cf., Osborn, Hunt, \& Jauch, 2002). Since space does not permit a detailed discussion, I provide some examples of the kinds of questions raised by a Relational Leadership Theory (RLT) framework, and discuss how these questions could be addressed and tested considering the potential contributions of both 
entity and relational perspectives. I suggest that we are best served not by arguing over whether entity or relational offers the "best" way, but rather by considering how our perspectives will be informed if we view these issues from multiple orientations (cf., Fairhurst and Putnam, 2004; Hosking, in press).

\section{The entity (individual reality) perspective}

As described above, entity perspectives assume individual agency - that "organizational life is viewed as the result of individual action" (Hosking et al., 1995, p. x). Individuals are thought of as "entities," with clear separation between their internal selves and external environments. These individuals are seen as possessing "the capacity to reason, to learn, to invent, to produce, and to manage" which serves as the basis for assumptions that "the 'reality' of management is understood as individual creation and control of order" (Hosking et al., 1995, p. x). Studies that align with this perspective explain relationships on the basis of the properties and behaviors of interacting individuals or organizations (Dachler \& Hosking, 1995).

The predominant entity perspectives exploring relational leadership issues are the "relationshipbased" approaches to leadership research (Graen \& Uhl-Bien, 1995). From this perspective, leadership can be seen as a two-way influence relationship between a leader and a follower aimed primarily at attaining mutual goals (Brower et al., 2000; Graen and Scandura, 1987; Graen and Uhl-Bien, 1991; Graen and Uhl-Bien, 1995; Hollander, 1978; Hollander, 1979). In relationship-based approaches, the focus is on interpersonal relationships, most often among leader-member dyads (Graen and Scandura, 1987; Uhl-Bien et al., 2000), but also leadership relationships that occur between a leader and a group (Hollander, 1964; Howell and Shamir, 2005) or among triads (Offstein, Madhavan, \& Gnyawali, 2006) or larger collectivities (Balkundi and Kilduff, 2005; Graen and Graen, 2006; Graen and Uhl-Bien, 1995). Relationship-based perspectives view relationships in a traditional sense of the word-a relationship as a particular type of connection existing between people related to or having dealings with each other (American Heritage Dictionary, 2000) - and relational processes are considered relative to individual characteristics that leaders and followers bring to their interpersonal exchanges.

\subsection{Leader-member exchange theory}

The most prominent relationship-based approach is the leader-member exchange (LMX) theory (Gerstner and Day, 1997; Graen et al., 1982; Graen and Uhl-Bien, 1995; Liden et al., 1997). According to Graen \& Uhl-Bien (1995), the central concept of LMX theory is that leadership occurs when leaders and followers are able to develop effective relationships (partnerships) that result in incremental influence (i.e., leadership, see Katz \& Kahn, 1978) and thus gain access to the many benefits these relationships bring (Gerstner \& Day, 1997). The theory describes how effective leadership relationships develop (Liden et al., 1997; UhlBien et al., 2000) among dyad "partners" (e.g., leaders and members, teammates, peers) to generate bases of leadership influence (Graen and Uhl-Bien, 1991; Graen and Uhl-Bien, 1995), as well as demonstrates the benefits of these leadership relationships for organizational outcomes (Gerstner \& Day, 1997).

LMX is an entity perspective because it focuses on the properties and behaviors of individuals as they engage in interactions with one another (cf., Dachler \& Hosking, 1995). Uhl-Bien et al. (2000) describe the relationship development process as beginning with two individuals, who engage in an interaction or exchange sequence (a series of interactions). The nature of these interactions depends on several things:

First, it depends on the characteristics each individual brings to the relationship, including their personal, physical, and psychological makeup that remains relatively stable and disposes them to approach interpersonal situations in a certain way (Phillips \& Bedeian, 1994). Second, it depends on the individuals' expectations of the exchange, which are developed based on past experience, outside information about the other, and implicit leadership theories or 'schemas' (Lord \& Maher, 1991). Third, it depends on their assessment of and reaction to the exchange both while it is occurring and in retrospect (Blau, 1964; Homans, 1961; Jacobs, 1971). (Uhl-Bien et al., 2000, p. 146-7).

In accordance with Dachler \& Hosking (1995), this is a "subject-object" understanding of relationships and an entity perspective: "When a person is understood as a knowing individual s/he is being viewed as a subject, distinguishable from the objects of nature. The latter implicitly are viewed as passive, as knowable and malleable only by the subject" (p. 3). In this case, the subject is the individual, and the object is 
the relationship, which lies in the mind of the individual: "Relations are considered only from the point of view of the entity [the individual] considered as the subject in that relationship" (Dachler \& Hosking, 1995, p. 3).

\subsection{Hollander's relational theory}

Another prominent relationship-based approach to leadership is that provided by (Hollander, 1964) and (Hollander, 1978). Hollander was one of the earliest scholars to adopt a focus on leadership as a relational process (Hollander, 1958), a two-way influence and social exchange relationship between leaders and followers (Hollander, 1979). According to Hollander \& Julian (1969), (1) leadership is a process involving an influence relationship, (2) the leader is one among other participants in this relationship, and (3) there are "transactions" (i.e., exchanges) that occur between leaders and followers, basic to which is the belief that rewards will be received for benefits given (cf., Homans, 1974; Jacobs, 1971).

Hollander's model is relational and focuses on process, but considers this process from the standpoint of individuals - making it an entity approach. For example, in the idiosyncrasy credit (IC) model of innovative leadership, leaders are given latitude for innovative behavior in a "credit-building" process that is a function of the followers' perceptions of the leader's competence and loyalty displays that engender follower trust in the leader (Hollander, 1958; Hollander, 1979; Hollander, 1992).

The essential point of the IC model is that leadership is a dynamic process of interpersonal evaluation: Individuals earn standing in the eyes of present or eventual followers and then have latitude for associations, including innovations associated with the leader role, that would be unacceptable for those without such status. (Hollander, 1992, pp. 72-73).

Moreover, while Hollander (1995) says that leadership is "a shared experience, a voyage through time" and the leader is not a sole voyager, he also says that "a major component of the leader-follower relationship is the leader's perception of his or her self relative to followers, and how they in turn perceive the leader" (p. 55). Hence, consistent with an entity perspective, this model describes processes that are located in the perceptions and cognition of the individuals involved in the relationship.

\subsection{Charismatic relationships}

A third entity perspective of relationship-based leadership is offered in views of charisma as a social relationship between leaders and followers (Howell and Shamir, 2005; Jermier, 1993; Kark and Shamir, 2002; Klein and House, 1995; Shamir, 1991; Weierter, 1997). This work began by considering the qualities of followers that lead them to identify with (Shamir, 1991) and react to leaders as charismatic (Klein and House, 1995; Shamir et al., 1993). It progressed into a consideration of the relationships that foster the perception of the leader as charismatic. For example, Weierter (1997) suggested that objective social forces define and set the potential for charismatic relationships and provide the framework within which subjective relationships are possible. Within his framework, different characteristics of followers (e.g., selfmonitoring and self-concept clarity) establish the role of personal charisma and the charismatic message of the leader in varying types of charismatic relationships (socialized, personalized, and social contagion) and affect the extent to which the charismatic relationship is maintained or re-created.

Building on Weierter (1997) and others, Howell \& Shamir (2005) integrate self-identity theory with two types of charismatic relationships - socialized and personalized - to develop propositions about how followers' self-concepts influence the type of relationship they form with the leader. They consider how followers may affect various stages of the charismatic relationship process, including susceptibility to charismatic leadership, responses to charismatic influence, empowerment of the leader, and consequences of the relationship.

\subsection{Relational and collective self}

A similar perspective to the one just described is offered in work applying social cognition and identity to leadership (Hogg, 2001; Lord et al., 1999; Shamir et al., 1993; van Knippenberg et al., 2004). This

work focuses on social self-concept - the extent to which individuals define themselves in terms of their relationships to others (Andersen and Chen, 2002; Brewer and Gardner, 1996; Lord et al., 1999). Within so- 
cial self-concept are two distinct constructs: relational self, which emanates from relationships with significant others, and collective self, which is based on identity with a group or social category.

\subsubsection{Relational self}

According to Brewer \& Gardner (1996), "At the interpersonal level, the relational self is the self-concept derived from connections and role relationships with significant others" (p. 84). It is defined in terms of relationships with others in specific contexts - the sense that the self is construed from the responses and satisfaction of the other person in the relationship. Self-worth comes from the feeling that one is behaving appropriately and acceptably with respect to the other (Brewer \& Gardner, 1996). This idea is further developed by Andersen \& Chen (2002), who describe the self as "relational-or even entangled-with significant others" which "has implications for self-definition, self-evaluation, self-regulation, and most broadly, for personality functioning, expressed in relation to others" (p. 619).

Andersen \& Chen (2002) suggest that an individual's overall repertoire of relational selves stem from all of his or her relationships, and serves as a major source of the interpersonal patterns the individual enacts and experiences in the course of everyday interpersonal life. Specifically, each individual has a relational self that is an embodiment of the unique self one experiences in relation to given significant others (i.e., a "significant-other representation"); when a significant-other representation is activated, the relevant relational self is activated accordingly. This infuses the working self-concept with knowledge that is a reflection of the self in relation to the significant other, setting into motion a "transference" of the significant-other representation to the individual who triggered it (Andersen \& Chen, 2002).

In a specific application of these concepts to leadership, Ritter \& Lord (2006) explore the issue of transference in leader-follower relationships by examining whether representations of relationships with former leaders that are cognitively stored by followers influence the perceptions of an incoming leader. In two studies, they demonstrate the existence of leader transference, with findings showing that leader effects on motivation and performance differ for individuals encountering a new leader who is similar versus one who is non-similar to previous leaders. Variables transferred from a similar leader are more likely to influence regulatory aspects of follower self-identity and goal setting than non-transferred variables.

Based on these results, the authors suggest that because transferred variables include information regarding how we see and feel about ourselves, the motivation to maintain positive self-views or eliminate negative self-views may be the underlying mechanism driving subsequent judgments and behavioral responses. The findings imply that leader transference processes may serve as a very early bias in the formation of such relationships, such that followers of leaders who activate a negative significant-other representation may be quickly turned off to relationship development attempts, while followers of a new leader who triggers a positive significant-other representation may be predisposed to form a beneficial exchange relationship with that leader (Ritter \& Lord, 2006).

Consistent with Ritter \& Lord (2006), van Knippenberg et al. (2004) call for more research on relational self-construal, or the extended sense of self that is based on the individual's role relationships with the leader. Such relational self-construal "renders mutual benefit and mutual interest more salient, and motivates the individual to take the other's interest to heart" (van Knippenberg et al., 2004, p. 828). Variables of interest for relational leadership based on self-construal might include motivations (self-interest versus other-interest, cf., Uhl-Bien \& Maslyn, 2003), affect (cf., Boyd \& Taylor, 1998), and evaluations (i.e., whether feedback is reinforcing of relational self-worth or disconfirming, Lord et al., 1999). Moreover, van Knippenberg et al. (2004) suggest that personal identification with the leader may motivate followers to be loyal to the leader, and cause followers to experience the leader's interest as a shared interest, enhancing leadership effectiveness. Relational self-construal may also play a role in dyadic leadership processes, offering a different perspective to relationship development and formation than the role-making (Graen \& Scandura, 1987) or social exchange (Liden et al., 1997; Uhl-Bien et al., 2000) explanations currently offered by LMX theory.

\subsubsection{Collective self}

Contrary to relational self-identities, which emanate from relationships with significant others, collective social identities do not require personal relationships among members (Brewer \& Gardner, 1996). Instead they come from identification with a group, an organization, or a social category. At the collective level, identification implies "a psychological 'merging' of self and group that leads individuals to see the self as similar to other members of the collective, to ascribe group-defining characteristics to the self, and to take the collective's interest to heart" (van Knippenberg et al., 2004, p. 828). This results in a "depersonalized" 
sense of self, "a shift towards the perception of self as an interchangeable exemplar of some social category and away from the perception of self as a unique person" (Turner, Hogg, Oakes, Reicher, \& Wetherell, 1987, p. 50, as quoted in Brewer \& Gardner, 1996, p. 83). Important at this level are the cognitive processes that help reinforce and promote the collective welfare of the group (Lord et al., 1999).

Hogg (2001) uses the concept of collective self to develop what he called a "Social Identity Theory of Leadership." Recognizing gaps in prior leadership theorizing that neglects consideration of the effects of larger social systems within which individuals are embedded, he offers a view of leadership as a "relational property" within a group: "Leaders exist because of followers and followers exist because of leaders" (Hogg, 2001, p. 185). Considering that leader and follower are interdependent roles embedded within a social system bounded by common group or category membership, he presents a model of leadership dynamics grounded in social identity cognitive processes of "self-categorization" and "depersonalization." Specifically, he proposes that leaders emerge, maintain their position, and are effective as a result of basic social cognitive processes among group members that cause them to: a) conceive of themselves in terms of an ingroup (i.e., self-categorization or identification with an ingroup prototype), b) cognitively and behaviorally assimilate themselves to the ingroup prototypical features (i.e., cognitive and behavioral depersonalization, which produces normative or stereotypic attitudes and behavior), and c) to perceive others through the lens of ingroup and outgroup prototypes rather than as unique individuals (i.e., perceptual depersonalization of others, producing homogenization) (Hogg, 2001). The implication is that if leadership is produced by these social psychological processes, then for an individual to be effective as a leader he/she must display the prototypical or normative characteristics of an ingroup member.

While the concepts of collective identity and collective self in the preceding paragraphs may sound like they more closely approximate a relational than entity perspective, they are included here because the processes described are primarily considered to occur in the "minds" of the individuals involved in the collectivity rather than in the social dynamic. In this way they appear more consistent with a constructivist (e.g., entity) than a constructionist (i.e., "relational") perspective. As described by Bouwen \& Hosking (2000), in a social constructivist perspective, "internal" processes are understood to be influenced by social relations, whereas social constructionism centers communication processes as the vehicle in which self and world are in ongoing construction.

\subsection{Social networks}

More recently, relationship-based leadership theory has begun to move beyond a focus on managersubordinate exchanges to consider other types of leadership relationships that can occur in the broader organization (Balkundi and Kilduff, 2005; Graen and Graen, 2006; Offstein et al., 2006; Sparrowe and Liden, 1997; Uhl-Bien et al., 2000). Although these approaches consider relationships in the context of larger collectivities, they are still entity perspectives in that they focus on individual perceptions of relational quality and relational ties, rather than a socially constructed reality (Hosking et al., 1995).

In a much overdue integration of social network theory and leadership, Balkundi \& Kilduff (2005) describe the key role that networks play in either supporting or negating the actions of individual leaders (whom they define as individuals who may or may not hold formal supervisory positions, cf., Bedeian \& Hunt, 2006). According to Balkundi \& Kilduff (2005), network theory has four core principles: the importance of relations between organizational actors; actors' embeddedness in social fields; the social utility of network connections (i.e., social capital); and the structural patterning of social life (Kilduff \& Tsai, 2003). Building upon these principles, and particularly the importance of understanding interactions between actors rather than a focus solely on the attributes of actors, they present a model that allows one to "zoom" in and out (Ibarra, Kilduff, \& Tsai, 2005) between individual level cognitions and the larger collectivities in which individual leaders function and interact. This model uses as a starting point cognitions in the minds of leaders, and then expands to consider the broader social structure of the organization and the interorganizational realm (Balkundi \& Kilduff, 2005).

This approach is an entity perspective because of its grounding in "cognitions in the mind of the leader" (p. 944), though at times the language used to describe the theoretical underpinnings sounds more relational:

An early treatment of network research on organizations stated that 'the social network approach views organizations in society as a system of objects (e.g., people, groups, organizations) joined by a variety of relationships' (Tichy, Tushman, \& Fombrun, 1979: 507), whereas a more recent survey represented organizational network research as a movement 'away from 
individualist, essentialist and atomistic explanations toward more relational, contextual, and systemic understandings' (Borgatti \& Foster, 2003). The importance of understanding relationships as constitutive of human nature was stated as follows in a recent book: 'Human beings are by their very nature gregarious creatures, for whom relationships are defining elements of their identities and creativeness. The study of such relationships is therefore the study of human nature itself' (Kilduff \& Tsai, 2003: 131). Our network approach locates leadership not in the attributes of individuals but in the relationships connecting individuals. (Balkundi \& Kilduff, 2005, p. 942).

Despite the relational tone in this quote, network theory has still not approached the relational (social reality) perspective described by Hosking and others (Hosking, 1988; Dachler, 1992). From a relational orientation, network theory would focus on the dynamic interactions through which relational networks are enacted, including those that occur between people as well as those between people and other social constructions (e.g., constructions of natural and "man-made" things and events, such as markets, fair trade, etc.) (cf., Hosking, in press). Until now, network theory has appeared to be concerned with description (e.g., who talks to whom, who is friends with whom) and taxonomy (e.g., friendship network, advice network, ego network) of relational links, focusing primarily on "mapping" network interconnections (e.g., identifying the number and types of links that occur among individual actors), rather than on how relational processes emerge and evolve-e.g., how these interpersonal relationships develop, unfold, maintain, or dissolve in the context of broader relational realities (including other social constructions).

\subsection{1. $L M X-M M X$ sharing network theory}

In another integration of network theory and leadership, Graen (2006) offers a transformation of LMX theory to what he is now calling the "new LMX-MMX theory of Sharing Network Leadership" (p. 277). In this extension, he moves into what Graen \& Uhl-Bien (1995) called "Stage 4" LMX research: expansion of dyadic partnerships to group and network levels. Building upon earlier work viewing organizations as systems of interdependent dyadic relationships, or dyadic subassemblies (Graen \& Scandura, 1987), this approach recognizes the importance of both formal and informal influences on individual, team and network flows of behavior (cf., Katz \& Kahn, 1978). Describing two different types of working relationships, he calls for researchers to move beyond the more limited focus on manager-subordinate relationships to consider informal leadership that occurs outside formal reporting relationships - to address both LMX and MMX, with "LMX being vertical and MMX is every direction but vertical” (p. 276).

\subsubsection{Triads}

Consistent with Graen's (2006) extension of LMX theory, Offstein et al. (2006) propose extending LMX research beyond the dyad by introducing the triadic level of analysis. Using recently developed statistical models from network analysis (such as $p^{*}$ ), they develop a theoretical framework that not only allows for ways to identify and analyze triads but also go beyond network theory to explain why particular triads form and how they function. Specifically, they develop and explore the constructs of competitive and collaborative interdependence and introduce the notion of multiplexity within LMX triads, which suggests that the structure of a triad may be predicated on the content and nature of the relations that exist (Offstein et al., 2006). They suggest that triads are formed and exist to fulfill either competitive or collaborative motives, and depending on which of these tensions dominates, the management and outcomes of those triads are distinctly different. Moreover, they draw from Simmel (1950), Heider's (1958) balance theory, and Krackhardt's (1999) concept of Simmelian ties to describe how triad interactions differ from those in dyads, due to the more complex interactive dynamics that accompany the introduction of an additional person to the relational exchange.

\subsection{Rost's postindustrial leadership}

Finally, another perspective that sees leadership as relationship-based, and also considers these relationships in the broader context of the organization, is (Rost, 1991) and (Rost, 1995) definition of "postindustrial" leadership. Rost (1995) defines leadership as not what leaders do but what leaders and collaborators do together:

Leadership is an influence relationship wherein leaders and collaborators influence one another about real changes that reflects their mutual purposes. Leaders compete with other leaders for collaborators. Collaborators develop a relationship with leaders of their own 
choosing, not necessarily those who have authority over them. Leaders and collaborators may change places. There may be a number of leadership relationships in one organization, and the same people are not necessarily the leaders in these different relationships. The intended changes reflect the purpose or vision that leaders and collaborators have for an organization. That purpose is usually not static but is constantly changing as leaders and collaborators come and go, as the influence process works its effects on both leaders and collaborators, and as circumstances, environment, and wants and needs impact on the relationship and the organization. (Rost, 1995, p. 134).

In this way, Rost (1995) sees leadership as a multidirectional influence relationship (i.e., it can act in any direction, not just from top down) in which leaders and collaborators are the actors in the relationship: "If leadership is what the relationship is, then both collaborators and leaders are all doing leadership. There is no such thing as followership" (p. 133). He does not suggest that all actors in the relationship are equal in influence (he says this can almost never be the case); the influence patterns are inherently unequal, and reflect intended real changes that reflect the mutual purposes of the leaders and collaborators. Moreover, he sees these relationships as operating within a larger context of the organization in which multiple influence relationships are interacting with one another.

\subsection{Summary of entity perspectives}

In sum, entity perspectives approach relational leadership from the standpoint of relationships lying in individual perceptions, cognition (e.g., self-concept), attributes, and behaviors (e.g., social influence, social exchange). They view leadership as an influence relationship in which individuals align with one another to accomplish mutual (and organizational) goals. These perspectives assume and center a realist ontology. They presume an individually constituted reality, which conveys a view of leadership as a more individually-based, causal set of factors in the design and development of organizations (Dachler, 1992). Moreover, they have primarily focused on leadership as manager-subordinate exchanges under the condition of already "being organized" (Hosking \& Morley, 1988). Emerging work in relationship-based leadership, however, is beginning to call for expansion of relationship-based approaches beyond the manager-subordinate dyad (Balkundi and Kilduff, 2005; Graen, 2006; Offstein et al., 2006; Uhl-Bien et al., 2000), as well as recognition that leadership can occur in any direction (Rost, 1991; Rost, 1995) and that leadership is a relational property of a group (Hogg, 2001).

In contrast to entity approaches, relational perspectives (Hosking et al., 1995) see leadership as a fundamentally social-relational process of organizational design and change (Dachler, 1992). According to Dachler \& Hosking (1995), because the focus in the individual entity perspective is on properties and behaviors of interacting individuals or organizations, relational processes are left largely untheorized: "What usually gets ignored are the social processes by which leadership is constructed and constantly in the making" (p. 15). Relations, "are given little explanatory power beyond an unexplicated view that influence results from relationships between certain properties possessed by interacting entities" (Dachler \& Hosking, 1995, pp. 3-4). To explain what they mean by this, I turn next to a discussion of "relational" (multiple realities) perspectives.

\section{The "relational" (multiple realities) perspective}

A relational perspective assumes that social reality lies in the context of relationships - it "takes as primary the nexus of relations..., rather than focusing on discrete, abstracted phenomena" (Bradbury \& Lichtenstein, 2000, p. 551). Such a perspective is skeptical of the validity of mental models or inner representations - rather, it assumes that any formulations of thoughts and assumptions have to be understood in the context of ongoing conversations and relations (Holmberg, 2000):

Whereas more traditional approaches...emphasize the interplay between the outer world and how this is represented in the minds of actors in ways that lead to more or less effective behaviour, a relational understanding is an opportunity to focus on processes in which both the actor and the world around him or her are created in ways that either expand or contract the space of possible action. (p. 181).

Relational perspectives do not adopt traditional organizational and management language of "structures" and "entities"; instead, they view organizations as elaborate relational networks of changing persons, moving forward together through space and time, in a complex interplay of effects between individ- 
ual organizational members and the system into which they enter (Abell \& Simons, 2000; cf., Sayles, 1964). In this way, organizations change as a result of the "co-ordination" of people's language and actions in relation to each other at all levels and to the ever-changing larger socioeconomic environment (Abell \& Simons, 2000). Moreover, power is not a commodity, concentrated within certain individuals, but is distributed throughout the social field (Foucault, 1977).

Applied to leadership, a relational perspective changes the focus from the individual to the collective dynamic (e.g., to combinations of interacting relations and contexts). It sees an appointed leader as one voice among many in a larger coordinated social process (Hosking, in press). "Within a relational perspective appointed leaders share responsibility with others for the construction of a particular understanding of relationships and their enactment...leaders and those with whom they interact are responsible for the kinds of relationships they construct together" (Dachler and Hosking, 1995, p. 15). Whereas entity approaches focus their attention on the quality and type of interpersonal relationships that occur among interacting individuals and groups, relational perspectives emphasize the relational (i.e., "in relation to") - they view multiple realities of self and other as coevolving, or constructed "in relation" (Hosking, in press).

\subsection{Relational constructionism}

The most prominent work on relational perspectives in leadership is that of Hosking, Dachler, and colleagues (Dachler, 1988; Dachler, 1992; Dachler and Hosking, 1995; Hosking, 1988; Hosking and Fineman, 1990; Hosking and Morley, 1988; Hosking et al., 1995). Calling for a change in leadership research strategy that switched attention from leaders, as persons, to leadership as process, Hosking (1988) argued that "we need to understand leadership, and for this, it is not enough to understand what leaders do [emphasis added]" (p. 147). Instead, we must focus on processes - the influential acts of organizing that contribute to the structuring of interactions and relationships. In these processes, interdependencies are organized in ways which, to a greater or lesser degree, promote the values and interests of the social order; definitions of social order are negotiated, found acceptable, implemented and renegotiated (Hosking, 1988).

Similarly, Dachler (1992) argued that the main focus of leadership, management and organization research would be better directed at social processes rather than specific content issues (e.g., leader behaviors, contents of employee motivation), since such content issues are "not 'facts of an objective organizational reality', but an emergent reflection of socially constructed realities in constant change" (p. 171; cf., Rost, 1991). Both Hosking (1988) and Dachler (1992) see leadership as a process of organizing that breaks down the traditional distinction between "leadership of people" and "the management of organization." Rather than searching for traits, behavioral styles, or identifying particular types of leaders or people management techniques, a relational ontology raises different questions for leadership. For example, it asks how the processes of leadership and management in organizations emerge-e.g., how realities of leadership are interpreted within the network of relations; how organizations are designed, directed, controlled and developed on the bases of collectively generated knowledge about organizational realities; and how decisions and actions are embedded in collective sense-making and attribution processes from which structures of social interdependence emerge and in turn reframe the collectively generated organizational realities (see Dachler, 1992, p. 171).

The key difference between relational and entity perspectives is that relational perspectives identify the basic unit of analysis in leadership research as relationships, not individuals. However, relationships have a quite different meaning from entity perspectives:

By relationships we do not refer to the still dominating paradigmatic conception of basically instrumental and influence-based notions of interpersonal, intra-group, inter-group and other forms of relationships that are still for the most part implied in current theories and practice of relational phenomena. ... Relationships are inherently communicative ... [They are] subject to multi-meanings since they are produced and heard by others within a multitude of interdependent contexts ... [and] embedded ... in complex multiple and simultaneously activated relational networks. (Dachler, 1992, p. 173).

As described by Hosking (in press), the reference to relating should not be construed as a reference to one person communicating in face-to-face relations with another. Relational researchers are not speaking of interpersonal or intrapersonal processes between already known actors, but instead of the "relating of written and spoken language, as well as the relating of nonverbal actions, things, and events" (Hosking, in press). 
Consistent with this idea, the focus of relational perspectives is on processes of interaction, conversation, narrating, dialoguing, and multiloguing (Dachler \& Hosking, 1995). As described by Abell \& Simons (2000), relational perspectives adopt a narrative metaphor that engenders:

A shift in our understanding of organizations as 'things' towards experiencing them more as an array of stories, always in the act of construction whose meaning and relevance is contextdependent. Meaning is constantly negotiated and renegotiated in the relational act of conversation, deriving its meaning within the context of its particular sociocultural location. The world is seen as being brought into being via our collaborative 'storying' of our experience, implying that as humans, we can actively intervene in constructing the societies and organizations we'd like to see emerge (p. 161).

Hence, in a relational constructionist perspective, what is and how we know it are viewed as ongoing achievements constructed in sequences of acts/events (Hosking, 2000).

\subsection{Sayles (lateral relationships)}

Although not purely a relational approach, Sayles (1964) description of organizations as systems in which the actions of the manager are embedded not only in an organizational and environmental context but within a dynamic and unfolding history of role-bounded interpersonal relationships (Osborn, 1999) are more consistent with relational orientations than traditional entity perspectives. As described by Sayles, because the manager does not have a neatly bounded job but rather is placed in the middle of a stream of relationships, much, if not most of a manager's time is spent on lateral relationships (Ashforth, 1999). Management is an iterative and messy interpersonal process in which planning and decision-making are not separate managerial activities but rather a social process that is shaped by interactions with others (Stewart, 1999). "To the outsider, the organization may appear to be a stable monolith, but to the insider it more closely resembles a loosely coupled federation of departments" (Ashforth, 1999, p. 22). The organization is actively held together not by its policies and rules and procedures, but the web of interpersonal relationships that is built through ongoing interaction: "The one enduring objective [of managers] is the effort to build and maintain a predictable, reciprocating system or relationship" (Sayles, 1964, p. 258 as quoted in Ashforth, 1999, p. 23).

\subsection{Drath and Murrell's "relational leadership"}

The relational perspective is consistent with what Drath (2001) and Murrell (1997) individually refer to as Relational Leadership. According to Drath (2001), leadership is not personal dominance (the more traditional leader-centric models) or interpersonal influence (the two-way influence process described by LMX and Hollander's exchange theory) but rather a process of relational dialogue in which organizational members engage and interact to construct knowledge systems together. Leadership is generated by bringing in increasing numbers of increasingly responsible people to produce an unfolding of ever more involving and complex knowledge principles. This relational dialogue enhances the capacity of a system to accomplish leadership tasks at various levels of complexity. In this way, "the very idea of leadership - what it is and how it works and even how people even know it when they see it - is in the process of changing... Nothing less than a revolution of mind is required, a shift in order of thought, a reformation of how leadership is known" (Drath, 2001, p. 124).

Murrell (1997) sees leadership as shared responsibility: "Leadership is a social act, a construction of a 'ship' as a collective vehicle to help take us where we as a group, organization or society desire to go" ( $\mathrm{p}$. 35). He describes a model of relational leadership in which the focus is broadened to include "more parties to the process than just the leader," and "more than just the leader-follower exchange relationship" (p. 39). His approach moves past what he calls the hero myth that focuses on the behaviors and characteristics of the individual leader to understanding the collective act of leadership (Murrell, 1997):

Relational leadership puts the emphasis of study squarely on human processes of how people decide, act, and present themselves to each other. In this study it is possible to see relationships other than those built from hierarchy and those in which nurturing and supporting roles could be legitimized as means of influence. It is also possible...to envision transforma- 
tional phenomenon where the social change process occurs well outside the normal assumptions of command and control. (p. 39).

Similar to Drath's (2001) view, Murrell states that by looking more deeply into the relational dynamics of organizations we may be on the verge of a completely new way of seeing leadership. He argues that by studying leadership that occurs relationally, researchers have an opportunity to account for many more of the social forces working to influence group and organizational behavior.

\subsection{Summary of relational perspectives}

In summary, relational perspectives view leadership as the processes by which social order is constructed and changed (Hosking \& Morley, 1988). In a relational perspective, self and other are not separable but coevolving in ways that need to be accounted for in leadership research (cf., Bradbury \& Lichtenstein, 2000). As described by Hosking (in press), a relational discourse does not view process as "intra" or "interpersonal" or as individual cognitions and acts, but rather as "local-cultural-historical" processes that are moving constructions of what is "real and good" (see also Gergen, 1994). Because of this, relational perspectives do not seek to identify attributes or behaviors of individual leaders but instead focus on the communication processes (e.g., dialogue, multilogue) through which relational realities are "made" (Hosking et al., 1995). They share an emphasis on communication and on language as a means of communication (Fairhurst \& Putnam, 2004); they see dialogue as a dialectical movement between and among human (and nonhuman) phenomena in which true interaction or real meaning emerges in the "space between" (Bradbury \& Lichtenstein, 2000). A relational perspective views leadership as social reality, emergent and inseparable from context (Dachler and Hosking, 1995; Hosking, 1988) - an iterative and messy social process that is shaped by interactions with others (Sayles, 1964).

\section{Comparing entity and relational perspectives of relational leadership}

In comparing these two approaches, we can see common themes emerging across entity and relational perspectives that have important implications for leadership research and practice. The most basic underlying theme is the emphasis of both perspectives on relationships, though the meaning of relationship differs across the perspectives. Entity perspectives (e.g., relationship-based leadership) emphasize the importance of interpersonal relationships, while relational perspectives (e.g., relational constructionism) emphasize the importance of "relating" and relatedness (i.e., the processes and condition of being in relation to others and the larger social system in constructing the meaning and reality of leadership). The former focuses primarily on leadership in conditions of already "being organized" while the latter considers leadership as "a process of organizing" (Dachler, 1992; Hosking and Morley, 1988).

A second theme is the call for leadership to be considered as separate from management and beyond the manager-subordinate dyad (Balkundi and Kilduff, 2005; Dachler, 1992; Graen, 2006; Hosking, 1988; Uhl-Bien, 2003). Relational leadership approaches allow for consideration of leadership relationships more widely than the traditional focus on the manager-subordinate dyad (Balkundi and Kilduff, 2005; Graen, 2006; Offstein et al., 2006; Seers, 2004; Uhl-Bien et al., 2000). Views of leadership as relational recognize leadership "wherever it occurs" (Hunt \& Dodge, 2000) and do not fall into the common practice (Bedeian \& Hunt, 2006) of using the terms leader and manager interchangeably (Drath, 2001; Hosking and Morley, 1988; Murrell, 1997; Rost, 1991; Uhl-Bien, 2005). Relational leadership also breaks down the distinction between leader and follower (Rost, 1995). It sees leadership not as management, or managers and subordinates, but instead as an interactive process engaged in by participants (Hosking, 1988; Hosking and Morley, 1988), collaborators (Rost, 1995), or partners (Graen and Uhl-Bien, 1995; Uhl-Bien et al., 2000).

A third theme is the need to better understand the context in which leadership is embedded. Work on relational and collective self (Brewer and Gardner, 1996; Ritter and Lord, 2006; van Knippenberg et al., 2004) recognizes that self-concepts are constructed in the context of interpersonal relationships and larger social systems. Social identity theory of leadership (Hogg, 2001) offers a framework for how group members, acting in relation, engage in social psychological processes that determine whether another will be recognized as a leader of the group (cf., Meindl, 1995). Social constructionism sees leadership as embedded in context-person and context are interrelated social constructions made in ongoing local-culturalhistorical processes (Dachler, 1988; Dachler and Hosking, 1995; Hosking, in press). Moreover, network theory and extensions of LMX into networks recognize that dyadic relationships are part of a larger sys- 
Table 1. Comparison of entity and relational perspectives

\begin{tabular}{|c|c|c|}
\hline & Entity & Relational \\
\hline $\begin{array}{l}\text { Ontological } \\
\text { assumptions }\end{array}$ & $\begin{array}{l}\text { Realist (assumes an objective reality) } \\
\text { - Views individuals in relationships as separate, } \\
\text { independent bounded entities }\end{array}$ & $\begin{array}{l}\text { Relational (assumes a social reality) } \\
\text { - All social realities - all knowledge of self and of other } \\
\text { people and things - are viewed as interdependent or } \\
\text { co-dependent constructions existing and known only in } \\
\text { relation }\end{array}$ \\
\hline $\begin{array}{l}\text { Approach to } \\
\text { process }\end{array}$ & $\begin{array}{l}\text { Cognitivist, constructivist } \\
\text { - Individuals performing internal cognitive } \\
\text { operations (separable from external social } \\
\text { influences) to make sense of and understand how } \\
\text { things really are }\end{array}$ & $\begin{array}{l}\text { Constructionist } \\
\text { - Person and context are interrelated social } \\
\text { constructions made in ongoing local-cultural-historical } \\
\text { processes }\end{array}$ \\
\hline $\begin{array}{l}\text { Approach to } \\
\text { methodology }\end{array}$ & $\begin{array}{l}\text { Views relating as an individual act } \\
\text { - These acts are reduced to one-way causal } \\
\text { relations with feedback; therefore, the basic } \\
\text { unit of analysis is the individual and studies are } \\
\text { operationalized using individual-level variables }\end{array}$ & $\begin{array}{l}\text { Assumes the primacy of relations } \\
\text { - Focuses on communication as the medium in which } \\
\text { all social constructions of leadership are continuously } \\
\text { created and changed }\end{array}$ \\
\hline $\begin{array}{l}\text { View of } \\
\text { leadership }\end{array}$ & $\begin{array}{l}\text { Emphasizes the importance of interpersonal } \\
\text { relationships } \\
\text { • Focuses primarily on leadership in conditions of } \\
\text { already "being organized" }\end{array}$ & $\begin{array}{l}\text { Emphasizes the importance of "relating" and } \\
\text { relatedness } \\
\text { - Considers leadership as "a process of organizing" }\end{array}$ \\
\hline
\end{tabular}

tem of interacting relationships that comprise organizations and social systems (Balkundi and Kilduff, 2005; Graen and Graen, 2006; Uhl-Bien et al., 2000).

Despite these similarities, there are also key differences between these approaches (see Table 1). These differences lie primarily in the philosophical underpinnings and methodologies used to examine leadership. In relational constructionism, no attempt is made to raise one approach or perspective over others, nor is there any intention to suggest that there is one true variant of relational to constructionism (Hosking \& Bouwen, 2000). Rather, the ontological emphasis is on leadership as something that cannot be known independently and outside of the scientific observer - what is seen is the leadership reality as leadership observers have constructed it (Dachler, 1988) (i.e., there are no leadership "truths," only multiple realities as constructed by participants and observers). In entity perspectives, it is assumed that there is an objective reality and the researcher's job is to uncover facts that reveal this reality; the ontological goal of knowing as completely as possible the real nature of leadership is answered through the authority of science (Dachler, 1988).

As such, relational constructionism assumes a relational ontology (i.e., all social realities - all knowledge of self and of other people and things - are viewed as interdependent or co-dependent constructions existing and known only in relation, Hosking \& Bouwen, 2000). Entity perspectives adopt a realist ontology, viewing individuals in relationships as separate, independent bounded entities (e.g., Dachler and Hosking, 1995; Gergen, 1994). Moreover, relational constructionism theorizes processes as historical and social co-ordinations. Entity perspectives adopt a cognitivist, constructivist approach that theorizes processes as individuals performing "internal" cognitive operations (separable from "external" social influences) to make sense of and understand how things really are (Hosking \& Bouwen, 2000). In terms of methodology, relational perspectives assume the primacy of relations (Dachler \& Hosking, 1995) and therefore focus on communication as the medium in which all social constructions of leadership are continuously created and changed. Entity perspectives view relating as an individual act, reduced to one-way causal relations with feedback; therefore, the basic unit of analysis is the individual (Dachler, 1988) and studies are operationalized using individual-level variables (e.g., surveys completed by individual respondents).

The difference in these approaches can be described as modern versus post-modern, but the point in illustrating these differences is not to set up a strict dichotomy or advocate one perspective over the otherin fact, quite the opposite. The intent is to highlight the key assumptions made by each approach, as well as their strengths and weaknesses, so that we can gain a broader understanding of the issues and opportunities that each has to offer. With a better understanding, we may be able to identify ways to advance new learning and new perspectives for the study of relational leadership. 
For example, if we set aside for a moment the key ontological and epistemological differences between entity and relational perspectives (e.g., whether reality lies in an individual or in a socially constructed reality) and focus on an objective of enhancing understanding about relational leadership, we can see that the biggest practical difference between the two perspectives is in how they approach, or operationalize, process. Entity perspectives, although they refer to process (e.g., social exchange, role-making), never really examine it. Approaches to study to date have been static, in the sense that if they do address process (which is rare) these examinations are limited "snapshots" of relational realities as viewed through the perceptions and reported behaviors of respondents (most often using a few variables operationalized with survey questions) (e.g., UhlBien \& Maslyn, 2003). Even with a greater number and more in-depth snapshots (e.g., longitudinal study), entity methodologies are limited in their ability to capture process, which requires a more dynamic examination of relational interactions as events emerge and unfold. Probably because of this, entity perspectives have done little to highlight the processes by which relationships develop to produce effective leadershipas Rousseau (1998) said, we know little about what is inside the "black box" of leader-member exchange.

Relational perspectives focus purely on process in local-historical-cultural contexts, to the extent that it is difficult to engage in meaningful theory-building in the traditional sense of the word. As noted by Bradbury \& Lichtenstein (2000), relational perspectives, which are dynamic approaches, are much harder to generalize. Therefore they require new standards of validity, reliability, and trustworthiness that are often uncomfortable to entity researchers. Moreover, relational perspectives can be seen as counter to attempts to produce a more unified theory of leadership: "One reason for this may be the inherently complex and psychological assumptions of interdependence and intersubjectivity" (Bradbury \& Lichtenstein, 2000, p. 561). Meeting the requirements of interdependence (a more complex understanding of causality) and intersubjectivity (e.g., a strong sense of personal identity) may be difficult for most leadership researchers who received little exposure to these kinds of issues and methods in their research training programs (Bradbury \& Lichtenstein, 2000, p. 561).

Without an understanding of the differing assumptions of these approaches and their associated methodologies, and with a continued "parting of the ways" or a failure of entity and relational perspectives to "speak to one another," we risk replicating the current state of understanding, thereby limiting our ability to advance knowledge regarding relational leadership. Therefore, I argue along with Bradbury \& Lichtenstein (2000), that a laudable goal is to gain a measure of integration across numerous methodologies: "Both normal, multipersonal science and relational science are necessary to generate a more complete understanding of the world" (p. 562).

With this as a background, I now turn to a discussion of Relational Leadership Theory. I intend Relational Leadership Theory (RLT) to represent a new framework for leadership theory and research. The objective of RLT is to enhance our understanding of the relational dynamics - the social processes - that comprise leadership and organizing. The key question asked by RLT is: What are the relational (social) processes by which leadership emerges and operates? I contend that we have little understanding currently of these relational dynamics because the vast majority of our existing studies of leadership have neglected to focus on process (Hosking, 1988; Hunt and Dodge, 2000; Hunt and Ropo, 1998; Ropo and Hunt, 2000). Therefore, RLT is, at its core, a process theory of leadership.

In presenting "Relational Leadership Theory" as an overarching framework for the study of the relational processes of leadership, I hope to contribute to creating what Hosking describes as a "transitional space" that includes "diverse and perhaps radically different 'paradigms' (Kuhn, 1970), 'discourses' (Deetz, 2000) or 'intelligibility nuclei' (Gergen, 1994)" (Hosking, in press) that, when considered relative to one another, can help illuminate key issues that need to be explored to increase our overall understanding of relational leadership.

\section{Toward a framework for Relational Leadership Theory}

In the opening quote of this article, Hunt \& Dodge (2000) refer to relational perspectives as recognizing leadership wherever it occurs, not restricted to a single or even small set of formal or informal leaders, and in its strongest form, functioning as a dynamic system embedding leadership, environmental and organizational aspects. Hunt (2004) describes these approaches as including social network analysis (Burt, 1992), leader-member exchange (Graen \& Uhl-Bien, 1995), lateral and distributive approaches (Osborn et al., 1980; Sayles, 1964), and social construction views (Dachler, 1988). We see from the review above that, although these approaches can all be considered relational, what they mean by relational is quite different. Therefore, the purpose of this discussion is not to present a "unifying" framework, but rather to describe how these approaches can engage with one another to contribute to and advance a study of Relational Leadership Theory. By combining efforts and engaging more open dialogue and adaptive tension 
(Uhl-Bien, Marion, \& McKelvey, 2004), we hope to learn more about one of the most fundamental, but least understood, aspects of leadership: the relational dynamics of leadership and organizing.

Moreover, as indicated in the review above, Relational Leadership Theory is the study of both relationships (interpersonal relationships as outcomes of or as contexts for interactions) and relational dynamics (social interactions, social constructions) of leadership. These can be seen as representing the difference between leadership in the condition of "already being organized" versus the condition of leadership as "a process of organizing" (Hosking, 1988). While historically the former has tended to focus less on process (and more on identifying associations between existing variables) and the latter more on process (though in local processes more than in broader contexts) (Hosking, 1988), in the sections below I describe how process can be considered in both perspectives. Before I do this, I offer a brief definition of relational leadership and how it can be distinguished from other types of social interactions.

\subsection{Relational Leadership Theory}

Relational Leadership Theory is offered as an overarching framework for the study of the relational dynamics that are involved in the generation and functioning of leadership. Contrary to other studies of leadership, which have focused primarily on the study of leadership effectiveness, Relational Leadership Theory focuses on the relational processes by which leadership is produced and enabled. It does not define leadership as holding a managerial position, nor does it use the terms manager and leader interchangeably (cf., Bedeian and Hunt, 2006; Hosking, 1988). It sees leadership as able to occur in any direction (Rost, 1991); in some variations, it may result in the breakdown of the distinction between who is leading and who is following (Rost, 1995), instead reflecting a mutual influence process (Hollander, 1978; Graen and Uhl-Bien, 1991; Uhl-Bien et al., 2000).

This is not to say that Relational Leadership Theory (RLT) precludes the study of manager-subordinate relationships. These relationships are still important to organizational functioning. However, Relational Leadership recognizes this as just one form of leadership-managerial leadership (cf., Uhl-Bien et al., 2004; Sjostrand et al., 2001) - and that other forms may be just as important (e.g., peer, network, upward, adaptive leadership). From a relational leadership perspective, "it is possible to see relationships other than those built from hierarchy $\ldots$ and to envision transformational phenomenon where the social change process occurs well outside the normal assumptions of command and control" (Murrell, 1997, p. 39). Non-hierarchical relationships that are nurturing and supporting could be legitimized as means of influence, and thus forms of leadership (cf., Fletcher, 2004; Gronn, 2002; Murrell, 1997; Pearce and Conger, 2003; Seers, 2004; Uhl-Bien, 2003). This focus breaks away from the prevailing socially constructed notion that position in an organization is necessarily a reflection of leadership. It allows us to account for more of the social forces working to influence group leadership (Gronn, 1999), and to view leadership responsibility as lying with the collective and not just the individual leader (Brown and Hosking, 1986; Fletcher, 2004; Marion and Uhl-Bien, 2001; Murrell, 1997).

Once we remove leadership from the study of managers, however, the challenge is: How do we identify whether the relational process is "really" leadership? There are multiple ways in which we could address this. One is to use an approach adopted by Dachler and Hosking who identify leadership as a modified form of "status" or influence. For example, as defined by Dachler (1988), relational leadership would address the processes by which: "(1) some social order is constructed; and (2) structurally differentiated groups emerge who proceed to perceive each other's 'qualifications' within constructed realities that become operative through the relationships inherent in or constitutive of social order" (p. 270). Hosking \& Morley (1988) described leaders as those who consistently contribute certain kinds of acts to leadership processes. For example, participants are leaders when they: "(1) consistently make effective contributions to social order, and (2) are both expected and perceived to do so by fellow participants" (Hosking \& Morley, 1988). This is also consistent with Hogg's social identity theory of leadership. As described by Hogg (2005): “Leadership is a relational term - it identifies a relationship in which some people are able to persuade others to adopt new values, attitudes and goals, and to exert effort on behalf of those values, attitudes, and goals" (Hogg, 2005, p. 53).

From this perspective, relational processes are leadership when the social influence that is generated contributes to the emergence of social order (i.e., emergent coordination) and new approaches, attitudes, goals, etc. (i.e., change). This perspective is consistent with the preceding review in which leadership was primarily described as some type of social influence relationship (e.g., Drath, 2001; Hollander, 1978; Graen and Uhl-Bien, 1995; Rost, 1991; Sayles, 1964), as well as with views that see leadership as change (Bryman, 1996). However, it differs in that it adds a perspective of leadership as an outcome (M. D. Mumford, personal communication, Feb., 2005) - i.e., leadership is generated in social dynamics - rather than leadership as a formal (managerial) role that drives organizational processes. 
Another, but perhaps more problematic, option is to predefine what a leadership relationship is, and then measure whether characteristics of that type of relationship are perceived by members in the relationship. This is the approach used in LMX theory and Graen's (2006) new version of LMX-MMX network leadership sharing theory (2006). Although this approach is valuable for identifying types of interpersonal relational contexts in which individuals operate, as House \& Aditya (1997) point out, a problem with this approach is that it is too limiting to a specific type of relationship. In other words, although it tells us about LMX relationships (or MMX, which is LMX applied to a peer), we learn little about other types of relationships that may occur in leadership interactions. Additionally, for our purposes here, we learn little about relational processes.

Therefore, in the section below, I adopt an approach more consistent with the former, and offer a general definition of relational leadership as a social influence process through which emergent coordination (i.e., evolving social order) and change (i.e., new values, attitudes, approaches, behaviors, ideologies, etc.) are constructed and produced. This definition should be applicable to both entity and relational perspectives, since relating is a dynamic social process that can be seen as acts of individuals (operating in a context) or as social constructions of interacting relationships and contexts; it can be seen as either creating (i.e., "organizing" condition) or shifting (i.e., "organized" condition) organizational processes (i.e., social order and action).

Moreover, Relational Leadership Theory as I present it here is not a theory in the traditional sense of the word. It is an overarching framework for a variety of methods, approaches, and even ontologies that explore the relational dynamics of leadership and organizing. As described by Fairhurst \& Putnam (2004), "The function of theory, as Deetz (1992, p. 74) purported, is conception not definition. In other words, theory should direct attention and focus rather than characterize the intrinsic nature of stable objects or mirror fixed attributes among them" (p. 8). Therefore, in the paragraphs below I attempt to direct attention and focus on potential questions that could be addressed by RLT, as well as describe some possibilities for how these can be tested considering the potential contributions of both entity and relational perspectives. In this discussion, I do not seek to identify whether entity or relational offers the "best" way to approach the study of relational leadership, but rather, how our perspectives will be informed if we view issues from multiple orientations (Fairhurst \& Putnam, 2004).

The discussion below is grounded in the following assumptions (cf., Hosking, 1988; Hosking and Fineman, 1990). First, leadership relationships are not restricted to hierarchical positions or roles. Instead relational leadership occurs throughout the organization: To study the leadership that occurs relationally is to "go more deeply into how human behavior is influenced at all levels" (Murrell, 1997, p. 39). Second, leadership relationships are identified by interactive dynamics that contribute to emergence or direction of social order and action. Third, relational leadership, at a collective level, gets at the "whole process by which social systems change and...the socially constructed roles and relationships developed that might be labeled leadership" (Murrell, 1997, p. 39). Finally, all relationships occur in a context and this context is important to the study of relational dynamics (cf., Osborn et al., 2002).

\subsection{Exploring relational dynamics}

The focus of Relational Leadership Theory research is a better understanding of the relational dynamics - the social processes - that comprise leadership and organizing. Relational Leadership Theory sees leadership as the process by which social systems change through the structuring of roles and relationships (Fletcher, 2004; Graen and Scandura, 1987; Seers, 2004; Senge and Kaeufer, 2001; Uhl-Bien, 2003; Uhl-Bien, 2005). For example, as described by Murrell (1997):

As leadership is shared and created jointly, so is the responsibility for structuring the organization... What this means is that people work together to define and develop their relationships not just as questions of influence and leadership, but also as questions of how to keep all of this moving and working together. How to...[work] becomes a question of how we relate to each other and work together. In answering this we lay out a structure...this structure becomes a product of the leadership relationships we envision as appropriate to our condition...[In this way] we become more consciously influencing the structure rather than only it influencing us. (p. 40).

Therefore, a key question asked by RLT is: How do people work together to define their relationships in a way that generates leadership influence and structuring? As noted in the quote, this question can be addressed from the standpoint of individual relationships (e.g., How do people work together to define their relationships?) and at a collective level (e.g., How do we keep all this moving and working together such that we become more consciously influencing the structure rather than only it influencing us?). In 
this way, relationships become both an "outcome" of investigation (i.e., How are leadership relationships produced?) and a context for action (i.e., How do relational dynamics contribute to structuring?).

\subsubsection{Relationships as an outcome}

As an outcome, the focus of investigation is on how leadership relationships are produced by social interactions. For example, relationships involve some type of connection or bond between an individual and another (a person, group, collectivity, organization, etc.). In some cases, social interactions produce these bonds, and in other cases they do not. However, we do not know why relational bonds form in some instances but not in others, or what factors contribute to formation of relational bonds. When social bonds (i.e., relationships) do result, they can be characterized as strong ties or weak ties (Granovetter, 1973), as well as more positive or more negative in nature (Uhl-Bien \& Maslyn, 2003). Moreover, they can be motivated by instrumental or affective drives (cf., Kellett et al., 2002; Kellett et al., 2006). Once formed, they provide a context for behavior - they establish norms and expectations that serve as guidelines for future behavior. However, they remain dynamic, e.g., if norms are violated, the relationship is threatened and relationships can dissolve or re-form in positive or negative ways (Uhl-Bien et al., 2000). Interestingly, although there is much theorizing about how leadership relationships develop (Graen and Uhl-Bien, 1991; Hogg, 2001; Hollander, 1964; Liden et al., 1997; Offstein et al., 2006; Uhl-Bien et al., 2000), we still know very little about these processes, and this is especially true if we expand our view of leadership beyond the manager-subordinate dyad.

Research addressing questions of how and why relational bonds develop as they do in leadership could adopt more of an entity perspective, a relational perspective, or a combination of the two. For example, research could examine constructivist concepts of how individuals' "internal" processes relate to how they understand and respond in the development of relationships within a larger context of social relations (an entity perspective). This work could continue the focus described above on social self-concept (relational and collective) (Brewer \& Gardner, 1996) and relational self-construal (van Knippenberg et al., 2004) as they function within relational processes, as well as consider how other variables identified as important antecedents in LMX research actually play out in relational dynamics (for reviews see Gerstner and Day, 1997; Liden et al., 1997; Schriesheim et al., 1999; Uhl-Bien et al., 2000). Moreover, it could consider the role of relational skills in leadership development (Uhl-Bien, 2003; Uhl-Bien, 2005), exploring whether some individuals possess a greater understanding of how to more consciously manage exchange processes (e.g., testing and reciprocity) to develop more effective relationships in a broader range of relational situations (e.g., lower v. higher relational favorability) than others, and whether and how individuals' implicit theories of relationships play a role in relationship development processes (Uhl-Bien, 2005).

Other research could adopt a constructionist perspective and examine the "skillful processes" of relationship development (Hosking, 1988) - the interrelated social, cognitive, and political processes which reflect and effect differing values and interests of participants. As described by Hosking (1988), these processes involve and create interdependence and inequalities of influence. Leaders are those who make especially salient contributions, and are recognized as such because participants construe their influence as compatible with the means by which they seek to satisfy their own values and interests. Research on relationships from this perspective would focus on the sense-making activities of participants (Weick, 1995), and investigate: a) acts which influence social constructions, b) those who are perceived to make the most consistent and significant contributions, and c) why they are perceived to do so (Hosking, 1988). This represents a view of leadership as a political process in which different participants seek to further different, sometimes conflicting values and interests. Therefore, such research would consider values and interests of participants as important reflections of "participants' constructions of their pasts, presents, and futures, along with understandings of cause-effect relationships, the conditions for acceptance or rejection of influence attempts, and distributions of resources" (Hosking, 1988, p. 154). These values and interests would be considered as central to participants' constructions of their social order and the terms in which they will "do business" (Hosking, 1988) or engage in relationship development.

A pure entity approach could pursue a research program on models like that of Uhl-Bien et al. (2000) or Barry \& Crant (2000), while a pure constructionist approach would adopt a post-modern discourse that "problematizes" leadership, e.g., assuming multiple realities and examining processes to consider how leadership relationships are variously constructed in different local-cultural-historical processes (Bryman, 1996; Hosking, in press). A combined approach would take a static model like that of Uhl-Bien et al. (2000) (see Figure 1 in their article) or Barry \& Crant (2000) and "bring it to life" by operationalizing it with a richer methodology than using only surveys (and would examine broader relationships than just 
the manager-subordinate dyad). "Rich" discourse analysis methodologies are available in the communication literature (see Putnam \& Fairhurst, 2001, for a review) that can help "set in motion" the models by gathering information about the processes that occur among the interacting individuals (Fairhurst \& Putnam, 2004). Such techniques include sociolinguistics, conversation analysis, cognitive linguistics, pragmatics (including speech acts, ethnography of speaking and interaction analysis), semiotics, rhetorical and literary studies, critical discourse analysis, and postmodern studies (Fairhurst \& Putnam, 2004). One could also use a combination of theoretical modeling with qualitative approaches (Bryman, 2004), grounded theory (Brown and Gioia, 2002; Parry and Meindl, 2002), case studies (Hunt and Ropo, 1998; Ropo and Hunt, 2000), etc.

Research could also examine the role of emotions in relational processes. Emotions play a key part in human interactions and dynamics (Ashkanasy et al., 2000; Humphrey, 2002; Rafaeli and Worline, 2001); therefore, future research could explore how various types of emotion are involved in leadership relationship development and, similarly, leadership emergence. As noted by Ashforth \& Humphrey (1995), the literature on emotions is divided between the (a) social constructionist and symbolic interactionist and (b) naturalist and positivist views - perspectives which differ in the extent to which they see emotions as cognitively or socially mediated. These differences, consistent with those between entity and relational perspectives, imply different directions in terms of how relational leadership and emotions could be explored. The former suggests research directions that focus on how different emotions influence the way individuals perceive and interact with others in the process of interpersonal relationship development (e.g, an entity perspective), while the latter would explore how emotion is constructed and spread (i.e., emotional contagion) in the human interactions that take place in ongoing local-cultural-historical contexts.

\subsubsection{Relational dynamics as a process of structuring}

As a process of structuring, or organizing, the focus of investigation in Relational Leadership Theory would be on how relational interactions contribute to the generation and emergence of social order. In contrast to traditional leadership perspectives that view structure as the prescribed framework of the organization, directed by managerial leaders, research investigating Relational Leadership Theory as a process of structuring (Barley, 1986; Fombrun, 1986; Giddens, 1984; Weick, 2001) or organizing (Dachler and Hosking, 1995; Hosking and Fineman, 1990) would view structure as "patterned regularity of interaction," in which leadership can result from everyday practices that organizational members participate in to construct the very "rules" of organizing that they follow (Willmott, 1981, p. 470; see also Hatch, 1997; Sjostrand et al., 2001).

For example, structuration theory assumes that organizations bring people into regular interaction with one another, and these repeated interactions are the foundation of social order (Dachler and Hosking, 1995; Hatch, 1997). Although the repeated interactions generate an image that organization is solid and stable and that formal managerial leaders are "in charge" of events that occur around them (Sjostrand et al., 2001; Streatfield, 2001), in reality, structures are highly dynamic and open to many small changes because they depend on the daily reproduction of the interaction patterns that constitute them: "If interaction patterns are disrupted or changed, then the social structure is opened to change" (Hatch, 1997, p. 180). Since leadership is often considered as creating change in organizations (Bryman, 1996), the implication of structuring is that leadership not only occurs through the managerial role, but also in the "disruptions" of daily interaction patterns that effect change in structure. These changes could be intentional or not intentional (i.e., "emergent," Uhl-Bien et al., 2004).

For example, Hosking (1988) describes how order is negotiated through a process of decision-making in which one or more participants conclude that the status quo "is changing, is likely to change, or is in need of change, and takes action on that basis" (p. 156). When this occurs, individuals interpret actual and potential events in relation to values and interests and in relation to beliefs about causal connections (i.e., relationships and networks) (Hosking, 1988). As individuals make decisions about whether and how to approach changes to the status quo, the role of networking becomes important:

The concept of 'networking' here is used to refer to a major organizing activity, one which may make all the difference to whether or not changes in the status quo are understood and handled in ways that protect or further values and interests.... Networking helps participants to (a) build up their knowledge bases and other resources; (b) come to understand the processes through which they can promote their values and interests, and (c) translate their understandings into action. (Hosking, 1988, p. 158-9). 
Therefore, the networking of decision-makers is an important element in establishing the context for generation of social order. However, this conceptualization of networking differs from traditional social network research in that research in this area would not adopt a methodology that maps and identifies the contacts between people. Instead it would focus on the dynamics of relationships (weak and strong) and investigate how processes of exchange, influence, and associated values and interests play into these processes (Hosking, 1988). It would examine the nature in which order is negotiated, both within and between groups, and explore what "counts" as leadership in contributing to this process.

Moreover, although structure is most apparent when interactions occur regularly, non-repetitive interactions and even non-interactions among particular groups or individuals may contribute to the social structure of the organization (Hatch, 1997). We can see the importance of this in the example of a strategic reorganization in which top managers may decide to reorganize but the success of their change effort is fully reliant upon whether individuals within the organization decide to change their daily patterns of interaction (Hatch, 1997). Traditional leadership theory has considered this likelihood, but has done so from the standpoint of resistance to change in which "subordinates" are noncompliant with directives from above. A structuring perspective sees the locus of leadership as not in the top managers and the compliance of followers but, rather, in the interactions that constitute the social structure (see also Weick, 2001). Managerial leaders can attempt to influence these patterns of interaction, but they are only one set of players in the larger relational dynamic of structuring, and often their control is much more illusory than traditional leadership theory suggests (Sjostrand et al., 2001; Streatfield, 2001).

In sum, the above examples are intended to illustrate some of the possibilities that can be considered by Relational Leadership Theory, but avenues for exploring relational leadership dynamics offer a wide variety of opportunities for future investigation. A critical factor to understand throughout this discussion, however, is that a key difference between relational leadership study and more traditional approaches is the recognition that leadership is relational, and cannot be captured by examination of individual attributes alone. Because of this, relational leadership, even when entity approaches are adopted, cannot be fully explained by more traditional leadership variables that do not regard relational context: "Influence in the abstract tells us little about the progress of the system represented by "leader-with-followers-seeking-results'" (Hollander, 1979, p. 162). For example, "Style is a relational concept, and fundamentally different from the idea of a trait because its effect and utility very much depend upon the reaction of followers" (Hollander, 1979, p. 163). Therefore, variables that are used should truly capture a relational understanding, and methodologies should provide richer insight into process and context than has been offered by traditional leadership approaches.

Such methodologies can be found in Bradbury \& Lichtenstein's (2000) review of relationality in organizational research. For example, relational leadership research may benefit from an understanding of participatory methods. These methods are "highly interpersonal, requiring direct communication between everyone involved in the project as to the goals, means, and outcomes of this research" (Bradbury \& Lichtenstein, 2000, p. 558). As such, they do not presume that the researcher knows the best design or the most appropriate issues to explore - rather the researcher and the organizational participants work in collaboration: "Participatory methods allow participants to cooperate in generating mutually defined projects that are accomplished through the interactions between researchers and subjects (Heron, 1996). These projects often create social change in the process of research engagement ..." (Bradbury \& Lichtenstein, 2000, p. 558).

Participatory methods include "insider/outsider research" (Bartunek \& Louis, 1996), "appreciative inquiry" (Cooperrider \& Srivasta, 1987), and "action science" (Argyris, Putnam, \& Smith, 1985). In insider/ outsider research the inside knowledge of a specific organization's practices is combined with a general knowledge of an organizational scholar; data are collected and analyzed in a fully collaborative effort between the insider and the scholar, and the result is model-driven understandings that can be better applied by organizational insiders (Bradbury \& Lichtenstein, 2000). Appreciative inquiry does not adopt the more traditional "problem-focused" orientation, as it can act as a constraint on human imagination and contribution to knowledge but, rather, posits that "we largely create the world which we later discover" (Bradbury \& Lichtenstein, 2000, p. 558). In this approach, the researcher enters the situation with an open mind and allows the issues to reveal themselves. Action science is based on consultative interactions between researcher and subjects where participants are encouraged to inquire into the set of assumptions and presuppositions that support their behaviors. "The goal is to create 'usable knowledge' (Argyris et al., 1985, p. ix) by articulating features of a science to inform how we might change the circumstances in which we live" (Bradbury \& Lichtenstein, 2000, p. 558). This approach posits that the generation and testing of propositions concerning the variables embedded in the status quo are a core concern to all. 
Relational leadership exploring structuring would benefit from qualitative approaches that "uncover the invisible assumptions that generate social structures" (Bradbury \& Lichtenstein, 2000, p. 557). Overall, this type of work benefits from intensive ethnographic and interview-based methodologies (Barley, 1986; Bradbury and Lichtenstein, 2000; Cooren and Fairhurst, 2004). Bradbury \& Lichtenstein (2000) offer some examples, including Schein's model of organizational culture (which provides analytic methods for studying assumptions and beliefs that give rise to culture) and Barley's (1986) structurationist analysis (which combines qualitative ethnographic data with quantitative analysis of coded data to see how beliefs translate into tangible organizational systems and structures).

Finally, relational leadership might also explore the role of aesthetics in leadership processes (Grint, 2005; Heron and Reason, 2001; Ropo, 2005; Strati, 2000). As defined by Taylor \& Hansen (2005), the study of aesthetics is concerned with knowledge that is created from sensory experiences, e.g., how one's thoughts, feelings and reasoning around their sensory experiences might inform their cognitions. Aesthetics can serve as a means for connection (Taylor \& Hansen, 2005), as patterns that connect mind and nature (Bateson, 1979), or provide a sense of belonging to or being a part of a social group (Sandelands, 1998). For example, aesthetics can be sensory reactions to leadership images (Jackson \& Guthey, in press) - images that evoke a sense of connection to a depicted leader.

On a more personal level, Ropo (2005) describes aesthetic perspectives to leadership that include reactions to beauty and the presence of the living body (e.g., the body as a source of knowing, lived experiences, sensuous perceptions). It could also include senses evoked from the physical places and spaces in which humans encounter one another with emotions, multiple voices, listening, touching, and bodily presence (Ropo, 2005). As applied to relational leadership, this perspective could focus on the aesthetic qualities of either the leader or the follower (i.e., an entity view), as well as consideration of how the relationship looks and feels-e.g., the extent to which it appeals to one's aesthetic sensibilities, both consciously and unconsciously (i.e., the relational view) (B. Jackson, personal communication, September, 2006).

\section{Conclusion}

Relationships - rather than authority, superiority, or dominance-appear to be key to new forms of leadership (Drath, 2001). Yet, while relationships are at the heart of many of the new approaches emerging in the leadership literature, e.g., distributed (Gronn, 2002), distributive (Brown \& Gioia, 2002), shared (Pearce \& Conger, 2003), post-heroic (Fletcher, 2004), and complexity (Marion \& Uhl-Bien, 2001), we know surprisingly little about how relationships form and develop in the workplace. Moreover, investigation into the relational dynamics of leadership as a process of organizing has been severely overlooked in leadership research (Hosking, 1988; Hosking and Fineman, 1990).

The predominant approach to the study of relationships in leadership has been LMX theory. Although LMX informs us about the value of relationships, and provides a theoretical description of how dyadic relationships form, it has likely reached stage 3 of Reichers and Schneider's "evolution of concepts" framework (Hunt \& Dodge, 2000). As noted by Murrell (1997), the breakthrough in the LMX literature is in legitimizing a question of how the relationships of leaders and followers better explain or help direct leadership research. However, to contribute to understanding it would have to evolve into more sociological or social-psychology orientations and go beyond the limited focus on dyadic or leader-follower singular relationships (Murrell, 1997). To do this, we need to morph what we have learned into a next stage of evolution - into a framework for the study of Relational Leadership Theory. We need to move beyond a focus on the manager-subordinate dyad or a measure of relationship quality to address the question of, what are the relational dynamics by which leadership is developed throughout the workplace?

Such an approach opens up the possibility for relational leadership as moving toward a more "postindustrial" model of leadership (Rost, 1991) - one that is not hierarchical, can address various forms of relationships (not just dyadic and not just "leader-follower" relationships), focuses on relational dynamics (rather than a more static state of relational quality with antecedents and outcomes), and allows us to consider leadership as a process of structuring (Giddens, 1984; Murrell, 1997). Investigating relational leadership will require richer methodologies than over-reliance on cross-sectional survey data using limited measures (Bradbury and Lichtenstein, 2000; Bryman, 2004). It would allow us to consider processes that are not just about the quality of the relationship or even the type of relationship, but rather about the social dynamics by which leadership relationships form and evolve in the workplace. In this way, it moves leadership beyond a focus on simply getting alignment (and productivity) or a manager's view of what is pro- 
ductive, to a consideration of how leadership arises through the interactions and negotiation of social order among organizational members.

\section{Acknowledgments}

The author would like to thank Russ Marion, Rebecca Grey, Bob Lord, George Graen, Brad Jackson, and four anonymous reviewers for their assistance and suggestions as this article was being developed.

\section{References}

Abell and Simons, 2000 - E. Abell and S. Simons, How much can you bend before you break: An experience of using constructionist consulting as a tool for organizational learning in the corporate world, European Journal of Work and Organizational Psychology 9 (2) (2000), pp. 159-175.

American Heritage Dictionary, 2000 - American Heritage Dictionary of the English language (10th Ed), Houghton Mifflin Company, Boston (2000).

Andersen and Chen, 2002 - S. M. Andersen and S. Chen, The relational self: An interpersonal social-cognitive theory, Psychological Review 109 (4) (2002), pp. 619-645.

Argyris et al., 1985 - C. Argyris, R. Putnam, and D. Smith, Action science, Jossey-Bass, San Francisco (1985).

Ashforth, 1999 - B. E. Ashforth, Leadership as an embedded process: Some insights from Sayles' Managerial Behavior, The Leadership Quarterly 10 (1) (1999), pp. 21-24.

Ashforth and Humphrey, 1995 - B. E. Ashforth and R. H. Humphrey, Emotions in the workplace: A reappraisal, Human Relations 48 (2) (1995), pp. 97-125.

Ashkanasy et al., 2000 - N. M. Ashkanasy, C. Hartel, and W. J. Zerbe, Editors, Emotions in the workplace: Theory, research and practice, Quorum Books, Westport. CT (2000).

Balkundi and Kilduff, 2005 - P. Balkundi and M. Kilduff, The ties that lead: A social network approach to leadership, The Leadership Quarterly 16 (6) (2005), pp. 941-961.

Barley, 1986 - S. R. Barley, Technology as an occasion for structuring: Evidence from observations of CT scanners and the social order of radiology departments, Administrative Science Quarterly 31 (1) (1986), pp. 78-108.

Barry and Crant, 2000 - B. Barry and J. M. Crant, Dyadic communication relationships in organizations: An attribution/expectancy approach, Organization Science 11 (6) (2000), pp. 648-664.

Bartunek and Louis, 1996 - J. Bartunek and H. Louis, Insider/outsider team research, Sage, Thousand Oaks (1996).

Bateson, 1979 - G. Bateson, Mind and nature: A necessary unity, E. P. Dutton, New York (1979).

Bedeian and Hunt, 2006 - A. G. Bedeian and J. G. Hunt, Academic amnesia and vestigial assumptions of our forefathers, The Leadership Quarterly 17 (2) (2006), pp. 190-205.

Blau, 1964 - P. M. Blau, Exchange and power in social life, Wiley, New York (1964).

Borgatti and Foster, 2003 - S. P. Borgatti and P. C. Foster, The network paradigm in organizational research: A review and typology, Journal of Management 29 (6) (2003), pp. 991-1013.

Bouwen and Hosking, $2000-$ R. Bouwen and D. M. Hosking, Reflections on relational readings of organizational learning, European Journal of Work and Organizational Psychology 9 (2) (2000), pp. 267-274.

Boyd and Taylor, 1998 - N. G. Boyd and R. R. Taylor, A developmental approach to the examination of friendship in leader-follower relationships, The Leadership Quarterly 9 (1) (1998), pp. 1-25.

Bradbury and Lichtenstein, $2000-$ H. Bradbury and B. Lichtenstein, Relationality in organizational research: Exploring the "space between," Organization Science 11 (5) (2000), pp. 551-564.

Brewer and Gardner, 1996 - M. B. Brewer and W. Gardner, Who is this "we"? Levels of collective identity and self representations, Journal of Personality and Social Psychology 71 (1) (1996), pp. 83-93.

Brower et al., 2000 - H. H. Brower, F. D. Schoorman, and H. H. Tan, A model of relational leadership: The integration of trust and leadermember exchange, The Leadership Quarterly 11 (2) (2000), pp. 227-250.

Brown and Hosking, 1986 - H. Brown and D. M. Hosking, Distributed leadership and skilled performance as successful organization in social movements, Human Relations 39 (1) (1986), pp. 65-79.

Brown and Gioia, 2002 - M. E. Brown and D. A. Gioia, Making things 'click': Distributive leadership in an online division of an offline organization, The Leadership Quarterly 13 (4) (2002), pp. 397-419.

Bryman, 1996 - A. Bryman, Leadership in organizations. In: S. R. Clegg, C. Hardy, and W. Nord, Editors, Handbook of organization studies, Sage Publications, London (1996), pp. 276-292.

Bryman, 2004 - A. Bryman, Qualitative research on leadership: A critical but appreciative review, The Leadership Quarterly 13 (4) (2004), pp. 397-419.

Burt, 1992 - R. S. Burt, Structural holes: The social structure of competition, Harvard University Press, Cambridge, MA (1992).

Cooperrider and Srivasta, 1987 - D. L. Cooperrider and S. Srivasta, Appreciative inquiry into organizational life, Research in Organizational Change and Development 1 (1987), pp. 129-169.

Cooren and Fairhurst, 2004 - F. Cooren and G. T. Fairhurst, Speech timing and spacing: The phenomenon of organizational closure, Organization 11 (6) (2004), pp. 793-824.

Dachler, 1988 - H. P. Dachler, Constraints on the emergence of new vistas in leadership and management research: An epistemological overview. In: J. G. Hunt, B. R. Baliga, H. P. Dachler, and C. A. Schriesheim, Editors, Emerging leadership vistas, Lexington Books/D. C. Heath and Co. (1988), pp. 261-285.

Dachler, 1992 - H. P. Dachler, Management and leadership as relational phenomena. In: M.v. Cranach, W. Doise, and G. Mugny, Editors, Social representations and social bases of knowledge, Hogrefe and Huber, Lewiston, NY (1992), pp. 169-178.

Dachler and Hosking, 1995 - H. P. Dachler and D. M. Hosking, The primacy of relations in socially constructing organizational realities. In: D. M. Hosking, H. P. Dachler, and K. J. Gergen, Editors, Management and organization: Relational alternatives to individualism, Avebury, Aldershot (1995), pp. 1-29. 
Deetz, 1992 - S. Deetz, Democracy in an age of corporate colonization, State University of New York Press, Albany, NY (1992).

Deetz, 2000 - S. Deetz, Describing differences in approaches to organisation science. In: P. Frost, R. Lewin and D. Daft, Editors, Talking about organisation science, Sage, Thousand Oaks (2000).

Drath, 2001 - Drath, W. (2001). The deep blue sea: Rethinking the source of leadership. Jossey-Bass and Center for Creative Leadership, San Francisco.

Fairhurst and Putnam, 2004 - G. T. Fairhurst and L. Putnam, Organizations as discursive constructions, Communication Theory 14 (1) (2004), pp. 5-26.

Fletcher, 2004 - J. K. Fletcher, The paradox of postheroic leadership: An essay on gender, power, and transformational change, The Leadership Quarterly 15 (5) (2004), pp. 647-661.

Fombrun, 1986 - C. J. Fombrun, Structural dynamics within and between organizations, Administrative Science Quarterly 31 (3) (1986), pp. 403-421.

Foucault, 1977 - M. Foucault, Discipline and punish: The birth of the prison, Allen \& Lane, London (1977).

Gergen, 1994 - K. J. Gergen, Realities and relationships, Harvard University Press, Cambridge (1994).

Gerstner and Day, 1997 - C. R. Gerstner and D. V. Day, Meta-analytic review of leader-member exchange theory: Correlates and construct issues, Journal of Applied Psychology 82 (6) (1997), pp. 827-844.

Giddens, 1984 - A. Giddens, The constitution of society: Outline of the theory of structuration, University of California Press, Berkeley, CA (1984).

Graen, 2006 - G. Graen, Post Simon, March, Weick, and Graen: New leadership sharing as a key to understanding organizations. In: G. Graen and J. A. Graen, Editors, Sharing network leadership, vol. 4, Information Age Publishing, Greenwich, CT (2006), pp. 269-279.

Graen and Graen, 2006 - G. Graen and J. A. Graen, Sharing network leadership, vol. 4, Information Age Publishers, Greenwich, CT (2006).

Graen et al., 1982 - G. B. Graen, M. A. Novak, and P. Sommerkamp, The effects of leader-member exchange and job design on productivity and satisfaction: Testing a dual attachment model, Organizational Behavior and Human Performance 30 (1) (1982), pp. 109-131.

Graen and Scandura, 1987 - G. B. Graen and T. Scandura, Toward a psychology of dyadic organizing. In: B.M. Staw and L.L. Cummings, Editors, Research in organizational behavior, vol. 9, JAI Press, Greenwich, CT (1987), pp. 175-208.

Graen and Uhl-Bien, 1991 - G. Graen and M. Uhl-Bien, The transformation of professionals into self-managing and partially self-designing contributors: Toward a theory of leadership-making, Journal of Management Systems 3 (3) (1991), pp. 49-54.

Graen and Uhl-Bien, 1995 - G. Graen and M. Uhl-Bien, Relationship-based approach to leadership: Development of leader-member exchange (LMX) theory of leadership over 25 years: Applying a multi-level multi-domain perspective, The Leadership Quarterly 6 (2) (1995), pp. 219-247.

Granovetter, 1973 - M. Granovetter, The strength of weak ties, American Journal of Sociology 78 (1973), pp. 1360-1380.

Grint, 2005 - K. Grint, Leadership: Limits and possibilities, Palgrave-Macmillan, Basingstoke (2005).

Gronn, 1999 - P. Gronn, A realist view of leadership. Paper presented at the Educational leaders for the new millenium-leaders with soul, ELO-AusAsia On-line Conference (1999).

Gronn, 2002 - P. Gronn, Distributed leadership as a unit of analysis, The Leadership Quarterly 13 (4) (2002), pp. 423-451.

Hatch, 1997 - M. J. Hatch, Organization theory: Modern, symbolic, and postmodern perspectives, Oxford University Press, Oxford (1997).

Heider, 1958 - F. Heider, The psychology of interpersonal relations, Wiley, New York (1958).

Heron, 1996 - J. Heron, Quality as primacy of the practical, Qualitative Inquiry 2 (3) (1996), pp. 41-56.

Heron and Reason, 2001 - J. Heron and P. Reason, The practice of co-operative inquiry: Research "with" rather than "on" people. In: P. Reason and H. Bradbury, Editors, Handbook of action research: Participative inquiry and practice, Sage, London (2001), pp. 179-188.

Hogg, 2001 - M. A. Hogg, A social identity theory of leadership, Personality and Social Psychology Review 5 (3) (2001), pp. 184-200.

Hogg, 2005 - M. A. Hogg, Social identity and leadership. In: D.M. Messick and R.M. Kramer, Editors, The psychology of leadership: New perspectives and research, Erlbaum, Mahwah, NJ (2005), pp. 53-80.

Hollander, 1958 - E. P. Hollander, Conformity, status, and idiosyncrasy credit, Psychological Review 65 (1958), pp. 117-127.

Hollander, 1964 - E. P. Hollander, Leaders, groups, and influence, Oxford University Press, New York (1964).

Hollander, 1978 - E. P. Hollander, Leadership dynamics: A practical guide to effective relationships, Free Press, New York (1978).

Hollander, 1979 - E. P. Hollander, The impact of Ralph M. Stogdill and the Ohio State leadership studies on a transactional approach to leadership, Journal of Management 5 (2) (1979), pp. 157-165.

Hollander, 1992 - E. P. Hollander, The essential interdependence of leadership and followership, Current Directions in Psychological Science 1 (2) (1992), pp. 71-75.

Hollander, 1995 - E. P. Hollander, Ethical challenges in the leader-follower relationship, Business Ethics Quarterly 5 (1) (1995), pp. 55-65.

Hollander and Julian, 1969 - E. P. Hollander and J. W. Julian, Contemporary trends in the analysis of leadership processes, Psychological Bulletin 71 (5) (1969), pp. 387-397.

Holmberg, $2000-$ R. Holmberg, Organizational learning and participation: Some critical reflections from a relational perspective, European Journal of Work and Organizational Psychology 9 (2) (2000), pp. 177-188.

Homans, 1961 - G. C. Homans, Social behavior: Its elementary forms, Harcourt, Brace, and World, New York (1961).

Homans, 1974 - G. C. Homans, Social behavior: Its elementary forms (revised edition), Harcourt, Brace, Jovanovich, New York (1974).

Hosking, 1988 - D. M. Hosking, Organizing, leadership, and skillful process, Journal of Management Studies 25 (2) (1988), pp. 147-166.

Hosking, 2000 - D. M. Hosking, Ecology in mind, mindful practices, European Journal of Work and Organizational Psychology 9 (2) (2000), pp. $147-158$.

Hosking, in press - D. M. Hosking, Not leaders, not followers: A post-modern discourse of leadership processes. In: B. Shamir, R. Pillai, M. Bligh \& M. Uhl-Bien (Eds.), Follower-centered perspectives on leadership: A tribute to the memory of James R. Meindl. Greenwich, CT: Information Age Publishing (in press).

Hosking and Bouwen, 2000 - D. M. Hosking and R. Bouwen, Organizational learning: Relational-constructionist approaches: An overview, European Journal of Work and Organizational Psychology 9 (2) (2000), pp. 129-132.

Hosking et al., 1995 - D. M. Hosking, H. P. Dachler, and K. J. Gergen, Editors, Management and organization: Relational alternatives to individualism, Avebury, Brookfield, USA (1995).

Hosking and Fineman, 1990 - D. Hosking and S. Fineman, Organizing processes, Journal of Management Studies 27 (6) (1990), pp. 583-604. 
Hosking and Morley, 1988 - D.-M. Hosking and I. E. Morley, The skills of leadership. In: J. G. Hunt, B. R. Baliga, H. P. Dachler, and C. A. Schriesheim, Editors, Emerging leadership vistas, Lexington Books/D. C. Heath and Co, Lexington, MA (1988), pp. 80-106.

House and Aditya, 1997 - R. J. House and R. Aditya, The social scientific study of leadership: Quo vadis?, Journal of Management 23 (1997), pp. 409-474.

Howell and Shamir, 2005 - J. M. Howell and B. Shamir, The role of followers in the charismatic leadership process: Relationships and their consequences, Academy of Management Review 30 (1) (2005), pp. 96-112.

Humphrey, 2002 - R. H. Humphrey, The many faces of emotional leadership, The Leadership Quarterly 13 (2002), pp. 493-504.

Hunt, 2004 - J. G. Hunt, What is leadership?. In: J. Antonakis, A. T. Cianciolo and R. J. Sternberg, Editors, The nature of leadership, Sage Publications (2004), pp. 19-48.

Hunt and Dodge, 2000 - J. Hunt and G. E. Dodge, Leadership déjà vu all over again, The Leadership Quarterly Review of Leadership 11 (4) (2000), pp. 435-458.

Hunt and Ropo, 1998 - J.G. Hunt and A. Ropo, Multi-level leadership: Grounded theory and mainstream theory applied to the case of general motors. In: F. Dansereau and F.J. Yammarino, Editors, Leadership: The multiple-level approaches, JAI Press, Westport, CT (1998), pp. 289-328.

Ibarra et al., 2005 - H. Ibarra, M. Kilduff, and W. Tsai, Zooming in and out: Connecting individuals and collectivities at the frontiers of organizational network research, Organization Science 16 (4) (2005), pp. 359-371.

Jackson and Guthey, in press - B. Jackson, E. Guthey, and E. Putting the visual into the social construction of leadership. In B. Shamir, R. Pillai, M. Bligh, M. Uhl-Bien (Eds.), Follower-Centered Perspectives on Leadership:A Tribute to the Memory of James R. Meindl. Greenwich, CT: Information Age Publishing (in press).

Jacobs, 1971 - T.O. Jacobs, Leadership and exchange in formal organizations, Human Resources Research Organization, Alexandria, VA (1971).

Jermier, 1993 - J. Jermier, Introduction-charismatic leadership: Neo-Weberian perspectives, The Leadership Quarterly 4 (3-4) (1993), pp. 217-233.

Kark and Shamir, 2002 - R. Kark and B. Shamir, The influence of transformational leadership on followers' relational versus collective selfconcept, Academy of management proceedings (2002).

Katz and Kahn, 1978 - D. Katz and R. L. Kahn, The social psychology of organizations, John Wiley and Sons, Inc, New York (1978).

Kellett et al., 2002 - J. B. Kellett, R. H. Humphrey, and R. G. Sleeth, Empathy and complex task performance: Two routes to leadership, The Leadership Quarterly 13 (5) (2002), pp. 523-545.

Kellett et al., 2006 - J. B. Kellett, R. H. Humphrey, and R. G. Sleeth, Empathy and the emergence of task and relations leaders, The Leadership Quarterly 17 (2) (2006), pp. 146-162.

Kilduff and Tsai, 2003 - M. Kilduff and W. Tsai, Social networks and organizations, Sage, London (2003).

Klein and House, 1995 - K. J. Klein and R. J. House, On fire: Charismatic leadership and levels of analysis, The Leadership Quarterly 6 (2) (1995), pp. 183-198.

Krackhardt, 1999 - D. Krackhardt, The ties that torture: Simmelian tie analysis in organizations, Research in the Sociology of Organizations 16 (1999), pp. 183-210.

Kuhn, 1970 - T. S. Kuhn, The structure of scientific revolutions (2nd Ed.), The University of Chicago Press, Chicago (1970).

Liden et al., 1997 - R.C. Liden, R.T. Sparrowe, and S.J. Wayne, Leader-member exchange theory: The past and potential for the future. In: G.R. Ferris, Editor, Research in personnel and human resource management, vol. 15, JAI Press, Greenwich, CT (1997), pp. 47-119.

Likert, 1961 - R. Likert, New patterns of management, McGraw-Hill, New York (1961).

Lipman-Blumen, 1996 - J. Lipman-Blumen, Connective leadership: Managing in a changing world, Oxford University Press, New York (1996).

Lord et al., 1999 - R. G. Lord, D. J. Brown, and S. J. Freiberg, Understanding the dynamics of leadership: The role of follower self-concepts in the leader/follower relationship, Organizational Behavior and Human Decision Processes 78 (1999), pp. 1-37.

Lord and Maher, 1991 - R. G. Lord and K. J. Maher, Leadership and information processing: Linking perceptions and performance, Unwin Hyman, Boston (1991).

Marion and Uhl-Bien, 2001 - R. Marion and M. Uhl-Bien, Leadership in complex organizations, The Leadership Quarterly 12 (2001), pp. 389-418.

Meindl, 1995 - J. Meindl, The romance of leadership as a follower-centric theory: A social constructionist approach, The Leadership Quarterly 6 (3) (1995), pp. 329-341.

Murrell, 1997 - K. L. Murrell, Emergent theories of leadership for the next century: Towards relational concepts, Organization Development Journal 15 (3) (1997), pp. 35-42.

Offstein et al., 2006 - E. H. Offstein, R. Madhavan, and D. R. Gnyawali, Pushing the frontier of LMX research: The contribution of triads. In: G. Graen and J. A. Graen, Editors, Sharing network leadership, vol. 4, Information Age Publishing, Greenwich, CT (2006).

Osborn, 1999 - R. N. Osborn, Sayles' managerial behavior: Its impact on understanding leadership and nuclear power safety, The Leadership Quarterly 10 (1) (1999), pp. 13-15.

Osborn et al., 1980 - R. N. Osborn, J. G. Hunt, and L. R. Jauch, Organization theory, John Wiley, New York (1980).

Osborn et al., 2002 - R. N. Osborn, J. G. Hunt, and L. R. Jauch, Toward a contextual theory of leadership, The Leadership Quarterly 13 (2002), pp. 797-837.

Parry and Meindl, 2002 - K. Parry and J. Meindl, Editors, Grounding theory and leadership in research: Issues and perspectives, Information Age Publishing, Greenwich, CT (2002).

Pearce and Conger, 2003 - C. L. Pearce and J. A. Conger, Shared leadership: Reframing the hows and whys of leadership, Sage, Thousand Oaks (2003).

Phillips and Bedeian, 1994 - A. S. Phillips and A. G. Bedeian, Leader-follower exchange quality: The role of personal and interpersonal attributes, Academy of Management Journal 37 (4) (1994), pp. 990-1001.

Putnam and Fairhurst, 2001 - L.L. Putnam and G.T. Fairhurst, Discourse analysis in organizations. In: F.M. Jablin and L. Putnam, Editors, The new handbook of organizational communication, Sage, Thousand Oaks (2001), pp. 78-136.

Rafaeli and Worline, 2001 - A. Rafaeli and M. Worline, Individual emotion in work organizations, Social Science Information 40 (1) (2001), pp. 95-123.

Ritter and Lord, 2006 - B. A. Ritter and R. G. Lord, Leadership transference: The impact of previous leaders on follower performance, Working paper (2006). 
Ropo, 2005 - A. Ropo, Aesthetic perspective to leadership. Paper presented in a professional development workshop at the National Academy of Management Meeting, Honolulu, Hawaii (2005).

Ropo and Hunt, 2000 - A. Ropo and J. G. Hunt, Leadership and organizational change: Some findings from a processual grounded theory study. In: J.A. Wagner III, Editor, Advances in qualitative organizational research, vol. 2, JAI Press, Stamford, CT (2000), pp. 169-200.

Rost, 1991 - J. C. Rost, Leadership for the twenty-first century, Praeger, London (1991).

Rost, 1995 - J. C. Rost, Leadership: A discussion about ethics, Business Ethics Quarterly 5 (1) (1995), pp. 129-142.

Rousseau, 1998 - D. M. Rousseau, LMX meets the psychological contract: Looking inside the black box of leader-member exchange. In: F. Dansereau and F.J. Yammarino, Editors, Leadership: The multiple-level approaches (contemporary and alternative), JAI Press, Stamford, CT (1998), pp. 149-154.

Sandelands, 1998 - L. E. Sandelands, Feeling and form in social life, Rowman and Littlefield, Lanham, MD (1998).

Sayles, 1964 - L. Sayles, Managerial behavior: Administration in complex organizations, McGraw Hill, New York (1964).

Schriesheim et al., 1999 - C.A. Schriesheim, S.L. Castro, and C.C. Cogliser, Leader-member exchange (LMX) research: A comprehensive review of theory, measurement, and data-analytic practices, The Leadership Quarterly 10 (1) (1999), pp. 63-113.

Seers, 2004 - A. Seers, Leadership and flexible organizational structures: The future is now. In: G.B. Graen, Editor, New frontiers of leadership, vol. 2, Information Age, Greenwich, CT (2004), pp. 1-31.

Senge and Kaeufer, 2001 - P. Senge and K. Kaeufer, Communities of leadership or no leadership at all. In: S. Chowdhury, Editor, Management 21c, Prentice Hall, New York (2001), pp. 186-204.

Shamir, 1991 - B. Shamir, Meaning, self and motivation in organizations, Organization Studies 12 (3) (1991), pp. 405-425.

Shamir et al., 1993 - B. Shamir, R. J. House, and M. B. Arthur, The motivational effects of charismatic leadership: A self-concept based theory, Organization Science 4 (4) (1993), pp. 577-594.

Simmel, 1950 - G. Simmel, The isolated individual and the dyad, The sociology of Georg Simmel, Free Press, Glencoe, IL (1950), pp. 118-136.

Sjostrand et al., 2001 - S.-E. Sjostrand, J. Sandberg, and M. Tyrstrup, Editors, Invisible management: The social construction of leadership, Thompson Learning, London (2001).

Sparrowe and Liden, 1997 - R. T. Sparrowe and R. C. Liden, Process and structure in leader-member exchange, Academy of Management Review 22 (1997), pp. 522-552.

Stewart, 1999 - R. Stewart, Some observations concerning Sayles' managerial behavior, The Leadership Quarterly 10 (1) (1999), pp. 17-20.

Stogdill and Coons, 1957 - R. M. Stogdill and A. E. Coons, Leader behavior: Its description and measurement, Ohio State University Press, Columbus (1957).

Stogdill et al., 1962 - R. M. Stogdill, O. S. Goode, and D. R. Day, New leader behavior description subscales, Journal of Psychology: Interdisciplinary and Applied 54 (2) (1962), pp. 259-269.

Strati, 2000 - A. Strati, The aesthetic approach to organization studies. In: H. Hopfl, Editor, The aesthetics of organization, Sage, London (2000), pp. 13-34.

Streatfield, 2001 - P. J. Streatfield, The paradox of control in organizations, Routledge, London (2001).

Taylor and Hansen, 2005 - S. S. Taylor and H. Hansen, Finding form: Looking at the field of organizational aesthetics, Journal of Management Studies 42 (6) (2005), pp. 1211-1231.

Tichy et al., 1979 - N. M. Tichy, M. L. Tushman, and C. Fombrun, Social network analysis for organizations, Academy of Management Review 4 (4) (1979), pp. 507-519.

Turner et al., 1987 - J. C. Turner, M.A. Hogg, P. Oakes, S. Reicher, and M. Wetherell, Rediscovering the social group: A self-categorization theory, Basil Blackwell, Oxford (1987).

Uhl-Bien, 2003 - M. Uhl-Bien, Relationship development as a key ingredient for leadership development. In: S. Murphy and R. Riggio, Editors, The future of leadership development, Lawrence Erlbaum Associates, New Jersey (2003), pp. 129-147.

Uhl-Bien, 2005 - M. Uhl-Bien, Implicit theories of relationships in the workplace. In: B. Schyns and J.R. Meindl, Editors, Implicit leadership theories: Essays and explorations, Information Age Publishing, Greenwich, CT (2005), pp. 103-133.

Uhl-Bien et al., 2000 - M. Uhl-Bien, G. Graen, and T. Scandura, Implications of leader-member exchange (LMX) for strategic human resource management systems: Relationships as social capital for competitive advantage. In: G.R. Ferris, Editor, Research in personnel and human resource management, vol. 18, JAI Press, Greenwich, CT (2000), pp. 137-185.

Uhl-Bien et al., 2004 - M. Uhl-Bien, R. Marion, and B. McKelvey, Complexity leadership theory: Shifting leadership from the industrial age to the knowledge era. Paper presented at the National Academy of Management Meeting, New Orleans, LA (2004).

Uhl-Bien and Maslyn, 2003 - M. Uhl-Bien and J. M. Maslyn, Reciprocity in manager-subordinate relationships: Components, configurations, and outcomes, Journal of Management 29 (4) (2003), pp. 511-532.

van Knippenberg et al., 2004 - D. van Knippenberg, B. van Knippenberg, D. de Cremer, and M. A. Hogg, Leadership, self, and identity: A review and research agenda, The Leadership Quarterly 15 (6) (2004), pp. 825-856.

Weick, 1995 - K. E. Weick, Sensemaking in organizations, Sage, Thousand Oaks (1995).

Weick, 2001 - K. E. Weick, Making sense of the organization, Blackwell, Oxford (2001).

Weierter, 1997 - S. J. M. Weierter, Who wants to play "follow the leader?" A theory of charismatic relationships based on routinized charisma and follower characteristics, The Leadership Quarterly 8 (2) (1997), pp. 171-193.

Willmott, 1981 - H. Willmott, The structuring of organizational structure: A note, Administrative Science Quarterly 26 (1981), pp. 470-474. 